\title{
Postharvest disorders of apples and pears
}

I+\ Aanicuture

Canadian Agriculture Library

Bibliotheque canadienne de l'agriculture

Ottawa K1A OC5
APR 291994
23

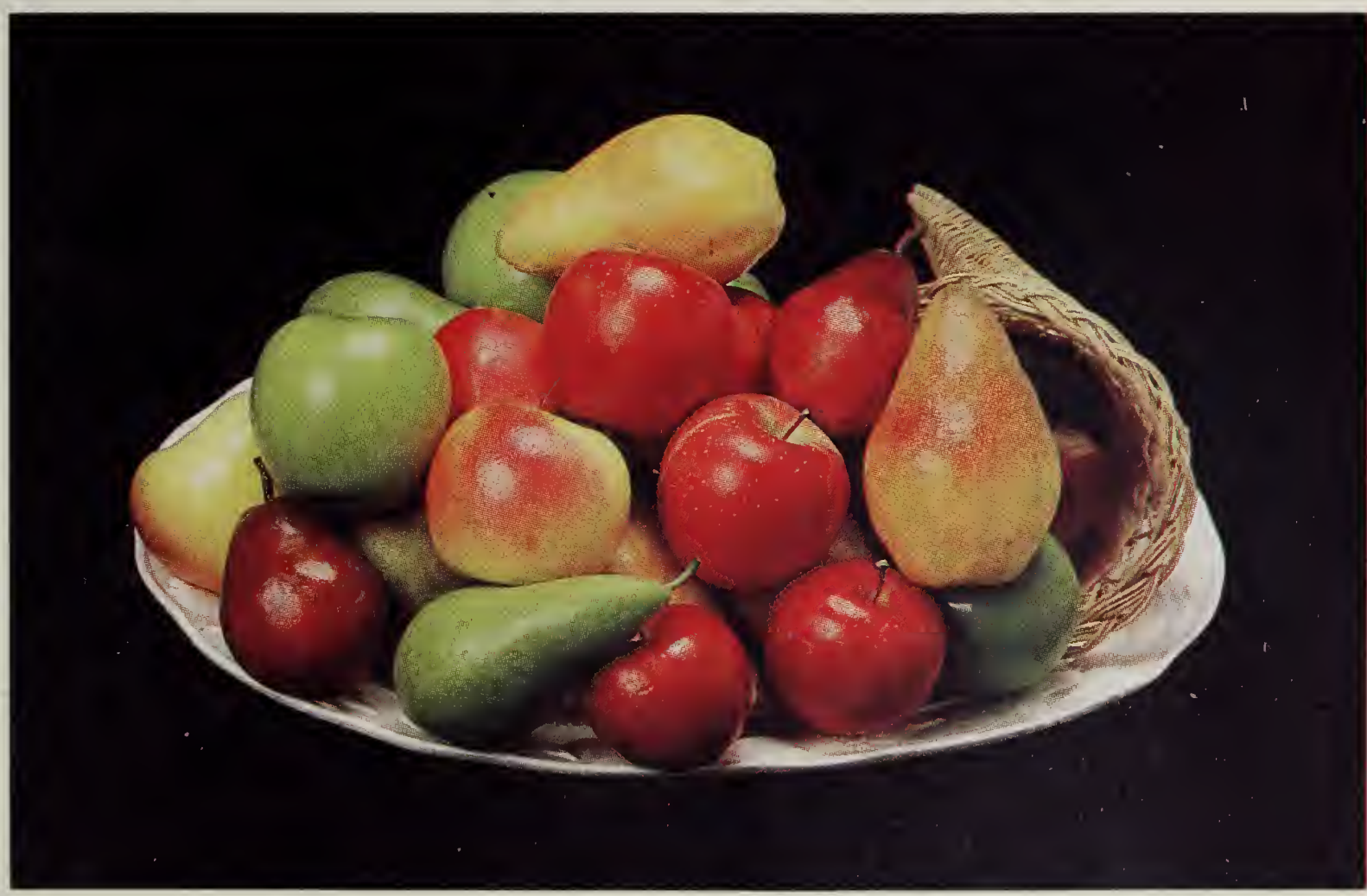


Printed with the financial support of the following:

Department of Pomology, University of California, Davis

Kearney Agricultural Center, University of California, Parlier New Brunswick Agriculture

Nova Scotia Department of Agriculture and Marketing

Nova Scotia Fruit Growers' Association

Washington State University 


\title{
Postharvest disorders of apples and pears
}

\section{Meheriuk}

Research Station

Summerland, British Columbia

\section{R.K. Prange}

Research Station

Kentville, Nova Scotia

\section{P.D. Lidster}

Western Region Headquarters

Ottawa, Ontario

\section{S.W. Porritt (retired)}

Research Station

Summerland, British Columbia

Recommendations for pesticide use in this publication are intended as guidelines only. Any application of a pesticide must be in accordance with directions printed on the product label of that pesticide as prescribed under the Pest Control Products Act. Always read the label. A pesticide should also be recommended by provincial authorities. Because recommendations for use may vary from province to province, consult your provincial agriculture representative for specific advice.

Cover illustration

Composition and photo by William Fleming, Summerland Research Station

\author{
Agriculture Canada Publication 1737/E \\ available from \\ Communications Branch, Agriculture Canada \\ Ottawa, Ont. K1A 0C7 \\ CMinister of Supply and Services Canada \\ Cat. No. A54-1737/1994E ISBN 0-662-21237-1 \\ Printed 1982. Revised 1994 6.3M-3:94 \\ Produced by Research Branch, Western Region Headquarters \\ Également disponible en français sous le titre \\ Affections après récolte de la pomme et de la poire
}




\section{Contents}

Diagram of apple anatomy 5

Acknowledgments 6

Preface 6

Guide for identifying fruit disorders 7

Apples 7

Pears 10

Physiological disorders of apples 11

Bitter pit 11

Breakdown 14

Carbon dioxide injury 18

Chemical injury 21

Core browning 24

Flesh browning 26

Freezing injury 27

Friction marking 30

Heat injury 31

Jonathan spot 32

Low-oxygen injury 32

Russet 34

Scald 35

Soft scald 38

Water core 39

Physiological disorders of pears 42

Alfalfa greening 42

Bitter pit (cork spot, Anjou pit) 42

Black end 42

Carbon dioxide injury 43

Chemical injury 43

Freezing injury 44

Core breakdown 46

Friction marking 47

Low-oxygen injury 50

Pink end 50

Russet 50

Scald 51

References cited 53 


\section{Diagram of apple anatomy}

Diagrammatic representation of an apple, Malus domestica Borkh., indicating anatomical terms used in this publication. Terms also apply to pears. (Reproduced from Carne 1948.)

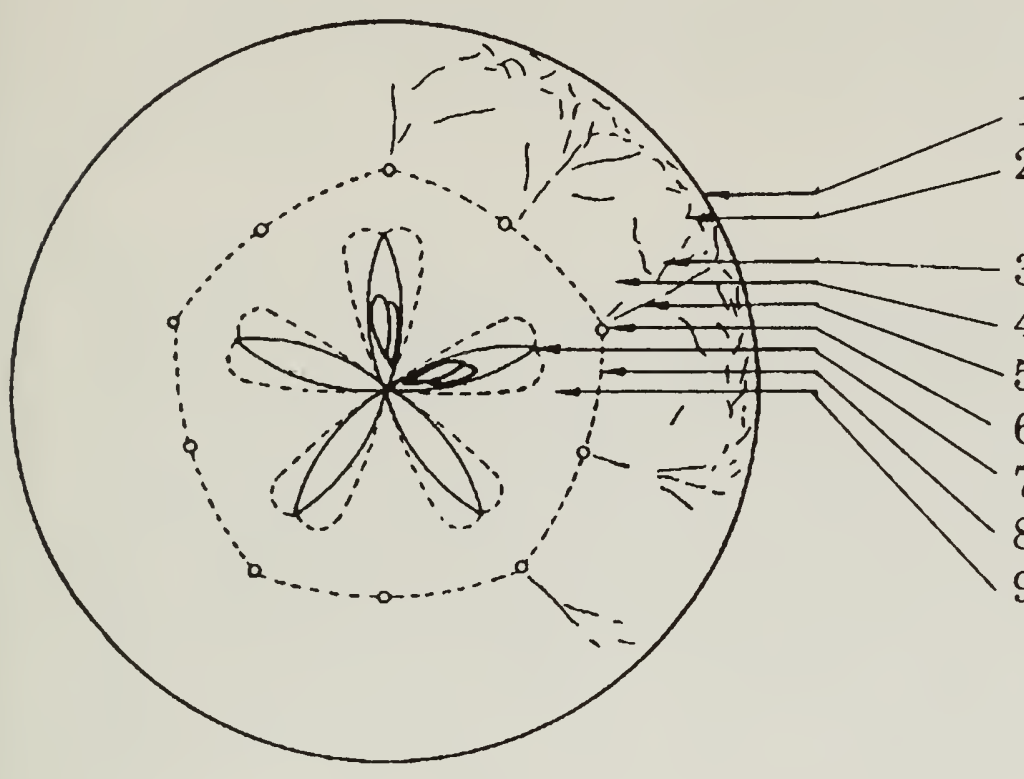

1. cuticle \& skin

2. subepidermal tissues with network of capillary

3. outer cortex

4. inner cortex

5. radial vascular

6. coreline vascular

7. carpel \& seeds

8. coreline

9. coreflesh

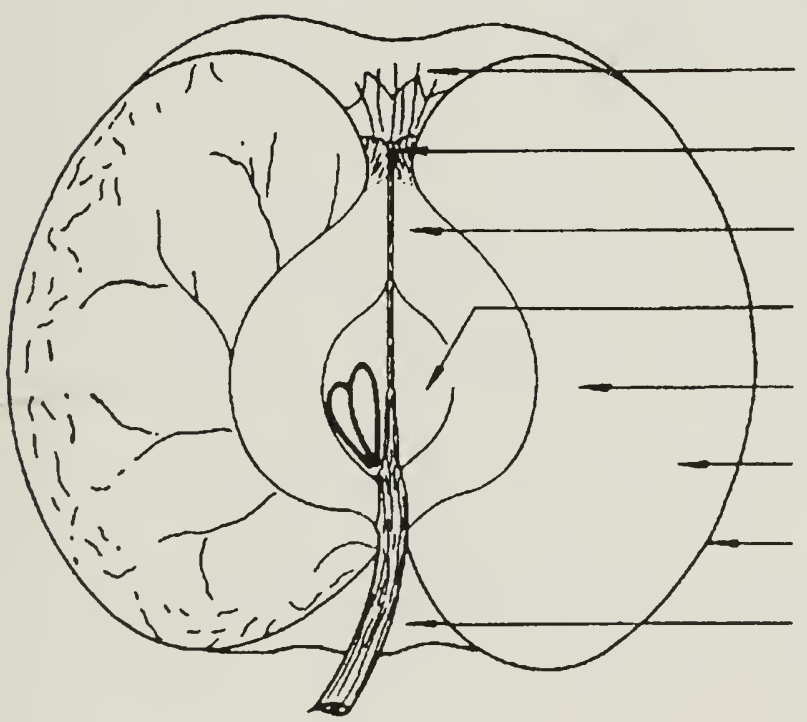

1. calyx depression or basin

2. calyx tube

3. core flesh

4. carpel \& seeds

5. inner cortex

6. outer cortex

7. cuticle \& skin

8. stem cavity or basin 


\section{Acknowledgments}

The authors are indebted to Linda Kerr and Justina Rogall for typing the draft and to Bill Fleming for preparing the slides. Special thanks go to Dr. T. Raese, United States Department of Agriculture, Wenatchee, Washington, and to Mr. David Johnson, Horticulture Research International, East Malling, England, for the use of several slides. Appreciation is extended to the staff at Western Region Headquarters in Ottawa for the final preparation of this publication and to the staff of Information and Planning Services for editing the French translation.

\section{Preface}

Fruit disorders can occur at harvest, during storage and transit, and at the retail level. Once properly identified, remedial action can then be taken in the orchard, packing house, or retail store to correct and prevent any further occurrence of these disorders.

This publication describes and illustrates typical nonparasitic disorders of apples and pears grown in North America, with emphasis on Canadian fruit-growing areas. Although fruit disorders are influenced by cultivar and climate, fundamental causes account for common features. We have therefore consulted references from temperate fruit-growing areas of the world in preparing this publication.

Information is also given on the causes of disorders and their control, based on current knowledge. Any procedure for the control of any disorder should be verified for suitability and compliance with federal and provincial regulations. 


\section{Guide for identifying fruit disorders}

\section{Apples}

\section{External Symptoms}

Carbon dioxide $\left(\mathrm{CO}_{2}\right)$ injury

Often similar to superficial scald, but affected areas are more likely to be rough, depressed, and well defined. Injury is associated with exposure to $\mathrm{CO}_{2}$ concentrations that are considerably higher than atmospheric.

\section{Chemical injury}

Small, dark areas of skin and underlying tissue at the lenticels. Lesions may be depressed because of desiccation. Injury is associated with exposure to phytotoxic chemicals in soluble or volatile form. Larger patches of dark skin and underlying tissue may be affected by prolonged exposure or higher concentrations of the chemical. Circular patches of injury may develop if liquid is retained between adjacent fruits or between fruits and container.

\section{Friction marking}

Diffuse, poorly defined areas of brown skin occurring prominently at high points on the fruit surface and associated with handling or transportation.

\section{Heat injury}

Associated with the hot-water wash during packing. This disorder resembles superficial scald, but unlike scald may develop early in storage, within 2 or 3 weeks of exposure to hot water.

\section{Jonathan spot}

Brown, circular spots $2-4 \mathrm{~mm}$ in diameter, affecting only the skin, often but not always at the lenticels. On red apples, spots may be almost black and may be concentrated in the most highly colored areas. Spots are lighter in color on green or yellow apples.

\section{Low-oxygen (alcohol) injury}

Dark-brown water-soaked skin lesions, sometimes including subepidermal tissue, in general appearance sometimes resembling soft scald. 
Fine lines or solid patches of cork tissue on the skin of the fruit or sometimes confined only to the stem cavity.

\section{Soft scald}

Smooth, irregular-shaped, but well-defined areas of brown skin occurring with no relationship to skin color, but usually not at stem or calyx ends of the fruit.

\section{Sun scald}

Bleached or brown areas on the side of the fruit exposed to the sun, sometimes accompanied by water-soaked subepidermal tissue and often becoming darker after removal from storage. The cortex tissue under lesions is likely to be a diffuse brown color, as well as bitter tasting.

\section{Superficial scald}

Diffuse, brown discoloration of the skin, somewhat rough in severe cases, developing after several months of cold storage and becoming more extensive after the fruit is removed to warm temperatures. Lesions are usually confined to nonblushed areas of red apples, but occur randomly on green or yellow fruit.

\section{Internal Symptoms}

Core browning

Diffuse brown tissue in the core area next to the carpels, occurring after several months of cold storage and becoming more extensive after the fruit is removed from storage.

\section{Flesh browning}

Diffuse, brown flesh in the cortex or also in the core tissue, often most evident in a transverse section at the juncture of the stem and core. Vascular elements are usually normal, and the general texture of the fruit is not noticeably abnormal.

\section{Internal carbon dioxide injury}

Brown, moist, fairly well defined areas in cortex or core tissue, sometimes associated with the main vascular elements. With time, lesions become light brown, dry, often with cavities developing in affected areas. External $\mathrm{CO}_{2}$ injury may also be present. 
Diffuse browning of outer cortex tissue, often well defined, usually moist and separated from the skin by normal tissue. Core tissue is usually not affected. Intact fruit may feel spongy when compressed. Soft scald may be present in the same fruit.

\section{Senescent breakdown}

Softening and browning of affected areas of cortex tissue, usually dry and poorly defined. Vascular elements are likely to be prominently brown, resembling freezing injury. Red skin becomes dark, and green or yellow skin becomes brown in the areas of breakdown. A symptom referred to as mealy breakdown is characterized by the whole fruit becoming dry and mealy; in severe cases deep external splitting occurs.

\section{Vascular breakdown}

Browning of the main vascular bundles and of some adjacent tissue. The remaining cortex may appear normal, or the affected areas may extend radially into cortex tissue.

\section{Water core}

Translucent liquid-infused tissue around the vascular bundles only, or affecting additional tissue within or outside the core area.

\section{External and internal symptoms}

\section{Bitter pit}

Small brown necrotic zones in the flesh $3-5 \mathrm{~mm}$ in cross section, more frequent toward the calyx portion of the fruit and sometimes visible through the skin as dark green or brown depressions, but sometimes red, particularly on Newtown and Golden Delicious.

\section{Freezing injury}

Brown discoloration of skin, often with water-soaked areas. The cortex tissue is brown, with contrasting darker brown vascular elements. Cavities may be caused by dehydration of moderately frozen tissue.

\section{Stem cavity browning}

Brown skin and underlying tissue of the stem cavity associated with McIntosh. Core browning accompanies stem cavity browning. 


\section{Pears}

\section{External Symptoms}

\section{Alfalfa greening}

Dark green specks, blotches, or streaks on the skin of Anjou pear, often accompanied by superficial cork (see bitter pit in pears).

\section{Chemical injury}

Dark spots at lenticels resulting from injury to skin and to subepidermal tissue caused by contact with volatile chemicals or chemicals in solution. Small depressions caused by dehydration often follow. Injury may show a circular pattern where liquid is retained between adjacent fruits.

\section{Friction marking}

Common to all cultivars. Diffuse, brown skin discoloration, particularly at high points on fruit with an irregular surface.

\section{Russet}

Russet that appears on pears is a genetic trait. Cultivars such as Bosc and Russet Barlett are completely russeted at harvest.

\section{Senescent scald}

Affects Bartlett, Bosc, Sierra, and Howell. Dark-brown skin discoloration begins as small, isolated areas, usually toward the calyx end of fruit, which turns yellow in storage. Large areas of skin may turn brown in continued storage or after the fruit is removed from storage. The fruit fails to ripen and soften normally. Brown skin may slough off.

\section{Superficial scald}

Affects Anjou, Packham's Triumph, and Winter Nelis. Diffuse, brown skin discoloration occurs after long storage and during ripening after storage. Symptoms often first develop around the neck of the pear.

\section{Internal symptoms}

\section{Carbon dioxide injury}

Browning of interior walls of carpels and sometimes of adjacent core tissue. With more extensive exposure to high levels of carbon dioxide, cortex tissue may become injured and turn light brown. Cavities may develop in damaged tissue. Carbon dioxide injury to the skin of pears has not been reported. 
Soft brown watery collapse of tissue around the core during or after ripening.

\section{Low-oxygen injury}

Late-harvested Bosc pears stored in $1 \% \mathrm{O}_{2}$ may develop low-oxygeninduced core browning. Low-oxygen injury in pears is rare.

\section{Freezing injury}

Translucent, water-soaked appearance of tissue while frozen. After some time in cold storage, damaged tissue may become light brown, often in a pattern conforming to the shape of the pear. A greenish water-soaked zone may be present in the outer cortex. Cavities may be present. The skin may give no evidence of freezing or may turn brown, accompanying brown subepidermal tissue.

\section{External and internal symptoms}

\section{Bitter pit (Anjou pit)}

Occurs often in Anjou and Packham's Triumph. Brown, corky lesions appear in the flesh, mainly toward the calyx end. An uneven surface, often with darker colored depressions, indicates pitted tissue. Uneven yellowing of skin occurs, particularly toward the calyx end.

\section{Black end}

Cortical tissue at the calyx end becomes hard and gritty and often turns black. No softening of affected tissue occurs during ripening of the fruit.

\section{Pink end or premature ripening}

Occurs primarily in Bartlett. This disorder is associated with cool, lateseason growing conditions. Early ripening and mixed maturity are typical, with some fruits yellowing at the calyx end; calyx lobes are often pink. Unlike core breakdown, premature ripening begins at the calyx end immediately under the skin.

\section{Physiological disorders of apples}

\section{Bitter pit}

Bitter pit is a disorder in which small, brown, somewhat dry, slightly bitter tasting lesions 3-5 $\mathrm{mm}$ in cross section develop in the flesh of the apple (Fig. 1). The disorder discussed here does not include cork 
spot, which is caused by boron deficiency. The first symptoms of bitter pit may be small, darkened, slightly depressed spots under the skin, usually in the calyx end of the fruit. The disorder does not affect the skin directly. It may appear before harvest or develop during storage. Internal lesions can occur anywhere in the tissue, from the core line to the skin, and are often associated with the vascular elements (Fig. 2). In severe cases, several lesions may coalesce to form larger necrotic areas. With time, the lesions at the skin darken, sometimes becoming reddish and more sunken, especially in Newtown and Golden Delicious.

Depending on the geographical location and the cultivar, various names have been given to disorders that resemble bitter pit. Terms used in the literature include stippen, Baldwin spot, York spot, crinkle, crinkle pit, cork spot, storage pit, tree pit, and lenticel blotch. Although somewhat different symptoms and etiology provide some justification for different terms, the anatomical features and a common association with mineral nutrition and other contributory factors indicate that they are variations of the same disorder. Even Jonathan spot appears to be closely related to pitting or corking abnormalities.

Bitter pit is a disorder that can affect all apple cultivars, irrespective of geographical location; it is influenced by climatic conditions and orchard practices. Cultivars highly susceptible to bitter pit are Baldwin, Boskoop, Bramley's Seedling, Cleopatra, Cox's Orange Pippin, Delicious, Granny Smith, Gravenstein, Grimes Golden, Jonathan, Merton, Worcester, Newtown, Rhode Island Greening, Stayman, Sturmer, and White Winter Pearmaine. Less susceptible cultivars are Golden Delicious, McIntosh, and Spartan (Fig. 3).

The cause for bitter pit is a mineral imbalance in the apple flesh, low levels of flesh calcium, and relatively high concentrations of potassium and magnesium. Low levels of calcium impair selective permeability of cell membranes and lead to cell injury and necrosis. Analysis of the pitted tissue relative to normal tissue in the same apple shows much higher concentrations of minerals, including calcium, and sugars. This finding may appear to contradict the explanation of calcium deficiency, but it is not unusual for necrotic tissue to lose carbohydrates and minerals (by leakage) to adjacent tissue. Dissolution of the middle lamellae by oxalic and succinic acid, and changes in proton secretion and potassium permeability, are other explanations for the development of bitter pit.

Electron microscopy has revealed pit initiation at 4-6 weeks after the petals fall; suspected cells had thicker cell walls and unusual cellular deposits. Calcium treatments help to preserve the ultrastructure of cellular bodies within the cell, thus preventing the formation of pitted tissue. Affected tissue appears to have a higher rate of respiration and ethylene production, more protein and pectin synthesis, and more migration of inorganic ions into the area. Movement of calcium from the skin to the core is suggested as a probable cause for the development of bitter pit near the surface of the apple. To prevent bitter pit in Cox's Orange Pippin, at least $5 \mathrm{mg}$ of calcium per $100 \mathrm{~g}$ of fresh weight of apple tissue (whole apple without seeds or stem) is needed. 

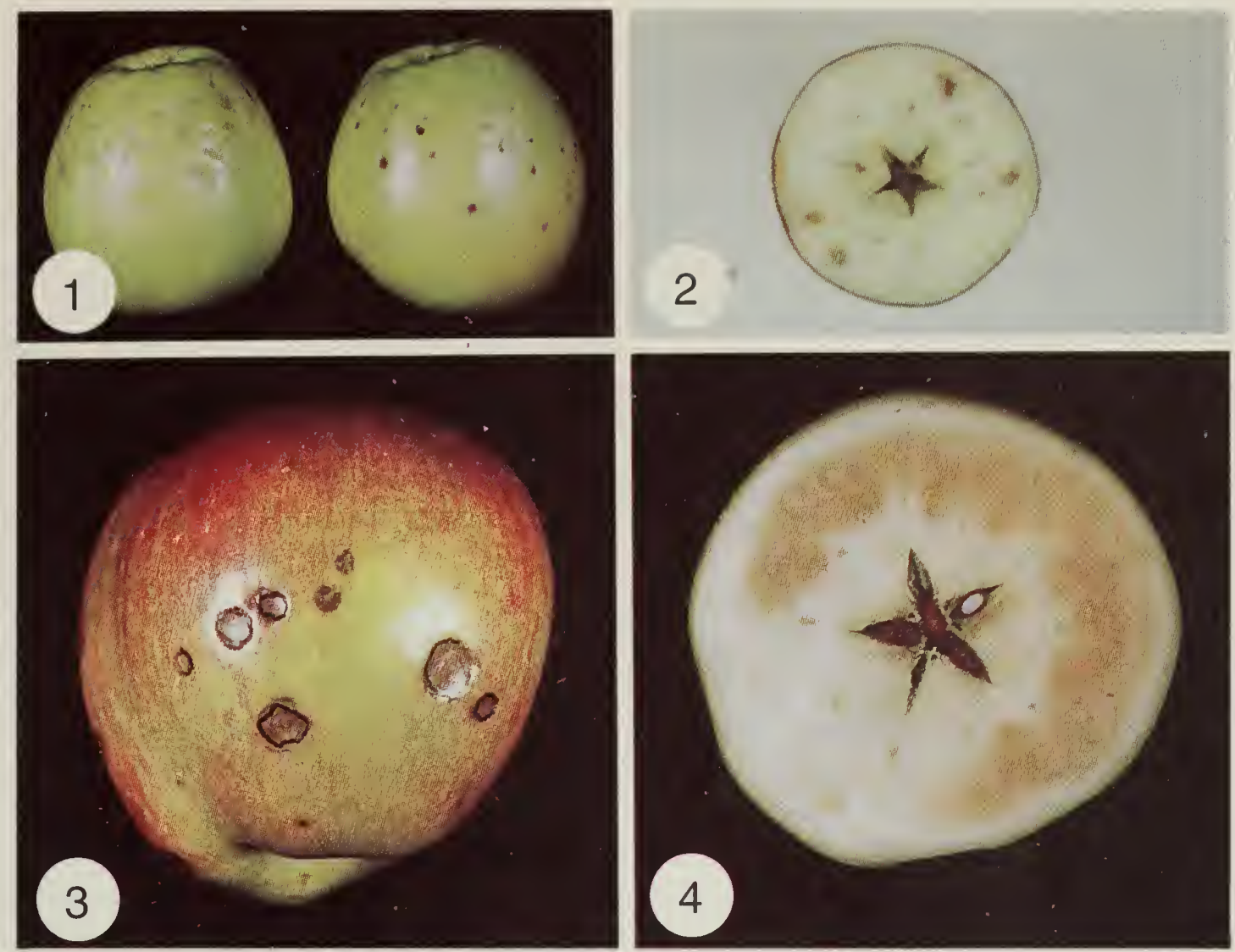

Fig. 1 Bitter pit (Golden Delicious)

Fig. 2 Bitter pit (Golden Delicious)

Fig. 3 Bitter pit (Delicious)

Fig. 4 Low-temperature breakdown (Newtown) 
Conditions and orchard practices that favor bitter pit include excessive tree vigor, immature fruit, large fruit because of a light crop, excessive thinning, high levels of potassium and magnesium, and unusually hot and dry weather, particularly if accompanied by wind. Practices that reduce bitter pit are annual bearing, moderate tree vigor, smaller fruit size, and harvesting of mature fruit. Nitrogen and magnesium sprays should not be applied in the summer. Fertilizer practices that result in low soil $\mathrm{pH}$ and high nitrogen should be avoided. Ammonium-based fertilizers are not recommended, because they tend to increase the incidence of bitter pit. Liming of soils with calcitic lime reduces bitter pit slightly but can also depress magnesium levels in the tree. Irrigation practices should be scheduled so as to avoid excessive fluctuations in soil moisture. Summer pruning can reduce competition for calcium between the fruit and vigorous new growth. If these orchard practices fail to control bitter pit, then summer sprays of calcium chloride, calcium nitrate, or comparable proprietary preparations and postharvest dips are recommended.

Storage conditions that minimize bitter pit include prompt cooling, low temperature, high relative humidity, and controlled atmospheres. The potential for the development of bitter pit during storage can be determined by dipping the fruit in a solution of 2000-5000 ppm ethephon and storing it at $20^{\circ} \mathrm{C}$ for 7-10 days. In another procedure, fruit is exposed to $1.0 \%$ acetylene at $20^{\circ} \mathrm{C}, 90 \%$ relative humidity for 1-2 days. Bitter pit is assessed after storing the fruit for an additional 6 days at $20^{\circ} \mathrm{C}$. A more recent method involves infiltrating the fruit with magnesium and holding it after treatment at $20^{\circ} \mathrm{C}$ for 2 weeks. The resulting incidence and the severity of bitter-pit-type lesions are a predictive index of fruit susceptibility to bitter pit or to other calcium-related disorders.

For additional information see Askew et al. 1959, 1960a, 1960b; Bangerth 1970, 1973, 1974; Bünemann 1972; Burmeister and Dilley 1991; Chamel and Bossy 1981; Coccuci et al. 1983; Eksteen et al. 1977; Faust and Shear 1968a, 1968b; Ferguson and Watkins 1983; Fukumoto and Nagai 1983; Greene and Smith 1979; Hewett and Thompson 1989; Ludders 1979; Mahanty and Fineran 1975; Mielke and Facteau 1988; Miller 1980; Perring 1986; Perring and Pearson 1986; Simons and Chu 1980, 1982, 1983; Steenkamp et al. 1983; Terblanche and Wooldridge 1979; Tukey 1977; Van der Boon 1980a, 1980b; Van Lune 1982; Wilton 1975.

\section{Breakdown}

Breakdown is a general term used to describe an internal disorder of fruit that is evident as browning and softening of the cortex tissue. The affected tissue may be dry and poorly defined, as in the case of senescent breakdown, or it may be moist and clearly separated from normal tissue, as is sometimes the case with low-temperature breakdown. In both forms, vascular bundles are likely to be prominently brown, similar in appearance to freezing injury. 
The immediate cause of tissue browning associated with breakdown is the failure of cell membranes to retain the phenolic precursors of browning within the vacuole. The cause of membrane failure leading to cell disorganization, however, is not clearly established. There is evidence that the accumulation of sorbitol or volatiles such as acetaldehyde and acetate esters is a contributing factor in the development of breakdown. Calcium, on the other hand, protects fruit from this disorder. It exerts some control over respiration, stimulates the uptake of sorbitol, and is effective in preventing membrane leakage by binding the phospholipids.

\section{Low-temperature breakdown}

In low-temperature storage, some apple cultivars develop metabolic disorders distinct from those caused by senescence. Examples include core flush in McIntosh, flesh browning in Newtown, breakdown in Jonathan and Cox's Orange Pippin, and soft scald in Grimes Golden and Winter Banana. As storage temperatures drop below the critical level of about $3^{\circ} \mathrm{C}$, the incidence and severity of low-temperature disorders increase.

Low-temperature breakdown in Cox's Orange Pippin and Jonathan begins as a diffuse browning of the outer cortex. The affected area is often well defined, usually moist rather than dry and mealy, and in the early stages is separated from the skin by an area of healthy tissue (Fig. 4). Both normal and affected tissues may have a fermented flavor. Vascular elements become browner than the cortex tissue. No external symptoms of the disorder may be evident, but the fruit is likely to be spongy when compressed. The healthy tissue may remain crisp and juicy and, unlike senescent breakdown, the disorder tends not to progress when fruit temperature is increased.

Senescent breakdown, however, may follow or accompany lowtemperature breakdown, and thus it is not always apparent which disorder prevails (as in Jonathan or Cox's Orange Pippin).

Changes in isoprenoid metabolism and higher levels of abscissic acid, acetic acid, and acetate esters have been implicated in lowtemperature breakdown. The disorder is favored by light crops, large fruit, advanced fruit maturity, cool weather in the latter part of the growing season, and high levels of humidity and $\mathrm{CO}_{2}$ in the storage atmosphere. Low oxygen $(<1.25 \%)$ can enhance the development of the disorder in Cox's Orange Pippin. Gibberellic acid $\left(\mathrm{GA}_{3}\right)$ can reduce the incidence of the disorder when used as a preharvest spray or postharvest dip. Warming the fruit to $18^{\circ} \mathrm{C}$ for several days during storage is also effective.

Low-temperature breakdown is associated with low levels of phosphorus and, to a leśser extent, with low levels of potassium and magnesium. Increased calcium levels in the fruit help to reduce the incidence of the disorder. Storage conditions that promote water loss from fruit are beneficial in reducing breakdown in Jonathan apples, a cultivar susceptible to low-temperature disorders. 
Cox's Orange Pippin, Fameuse, Grimes Golden, Jonathan, Northwest Greening, Rome Beauty, Wealthy, Ribston, and Winter Banana are susceptible cultivars. Less prone to the disorder are Delicious, Granny Smith, McIntosh, Rhode Island Greening, Spartan, Winesap, and York Imperial. McIntosh, however, can be sensitive to low temperatures under controlled-atmosphere conditions.

For additional information, see Autio et al. 1986; Eaves and Hill 1940; Faust et al. 1969; Fidler and North 1970; Meheriuk et al. 1984; Perring 1985; Perring and Pearson 1988; Scott and Wills 1979; Smith 1958; Webster and Lidster 1986; Wills and Scott 1972, 1976; Wills and Scriven 1979; Wills et al. 1978; Wills et al. 1973; Wills et al. 1976; Yogaratnum and Sharples 1982.

\section{Senescent breakdown}

As the name suggests, senescent breakdown is associated with ageing and is aggravated by advanced maturity, delayed cooling, high storage temperature, high humidity, extended storage, light crops, large fruit, and the presence of water core.

The disorder usually starts in tissue immediately under the skin, often near the calyx end (Fig. 5). When fruit is removed from cold storage and exposed to higher temperatures, the disorder advances rapidly to other parts of the fruit. Breakdown causes the skin of red cultivars to darken and the skin of green or yellow cultivars to turn brown. In susceptible fruit, bruising late in the storage period often precipitates breakdown.

Sometimes the whole apple becomes dry and mealy, and in some instances, large cracks appear in the specimen, e.g., mealy breakdown in McIntosh (Fig. 6). This form of senescent breakdown may occur on the tree (Lodi and Transparent) or during prolonged storage (McIntosh).

Senescent breakdown can occur in any apple cultivar. Susceptibility to the disorder is influenced by the calcium content of the fruit; foliar sprays or postharvest treatments with solutions of calcium salts are effective in reducing breakdown. Senescent breakdown in Jonathan correlates well with the water-soluble $\mathrm{K}$ :Ca ratio, but not with total or water-soluble $\mathrm{Ca}$. Controlled-atmosphere storage conditions that delay senescence also reduce the incidence of senescent breakdown. Cultivars such as Delicious and Winesap, though resistant to breakdown, often develop the disorder if water core is present (Fig. 7). High levels of sorbitol accumulate in tissue affected by water core, but the role of sorbitol in the development of breakdown is not understood. Sorbitol stimulates volatile production; high levels of acetaldehyde and acetate have been found in apples with breakdown. One report indicates a higher incidence of breakdown in late-picked daminozide-sprayed McIntosh apples (Lougheed et al. 1983).

Senescent breakdown in Spartan apples (Fig. 8) is not associated with low storage temperature, and unlike most forms of senescent 

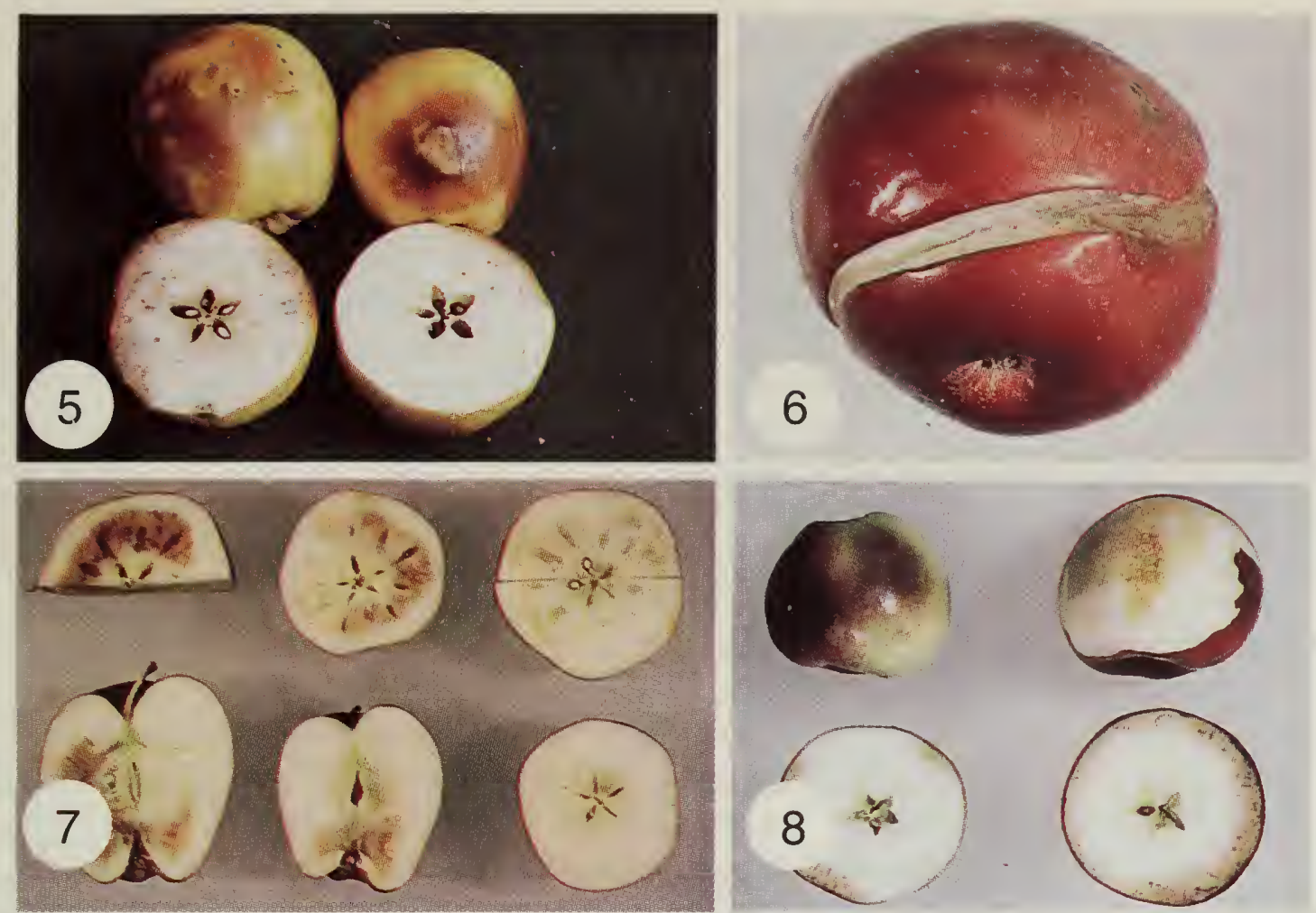

Fig. 5 Senescent breakdown (Golden Delicious)

Fig. 6 Mealy breakdown (McIntosh)

Fig. 7 Water core breakdown (Delicious)

Fig. 8 Senescent breakdown (Spartan) 
breakdown it is not clearly related to maturity. It is reduced or, in some cases, prevented by delayed cold storage or low-humidity storage. Spartan breakdown is negatively correlated to the calcium content of the fruit tissue. Calcium sprays or dips in calcium solutions are highly effective in reducing or preventing the disorder in this cultivar.

For additional information, see Autio et al. 1986; Bangerth 1973; Blanpied 1981; Bramlage et al. 1985; Clijsters 1965; Eaves and Hill 1940; Faust et al. 1969; Lidster 1983; Lougheed et al. 1983; Martin et al. 1969; Mason 1979; Perring et al. 1985; Pierson et al. 1971; Plagge and Maney 1937; Porritt and Meheriuk, 1973; Porritt et al. 1975; Roberts et al. 1965; Saks et al. 1990; Scott and Roberts 1968; Scriven and Wills 1984; Sharples 1964; Van Lune 1982; Wills 1981; Wills and Scott 1974; Wills et al. 1978.

\section{Vascular breakdown}

Vascular breakdown is a senescent disorder of apples that causes the main vascular bundles and some adjacent tissue to turn brown. The rest of the cortical tissue is normal, except in severe cases when affected areas extend radially into the flesh and impart a brownish, water-soaked appearance (Fig. 9). Senescent breakdown is usually present in apples with severe vascular breakdown. A form of vascular browning is found in overstored pears; this aspect is discussed under core breakdown of pears.

In Nova Scotia, vascular breakdown occurs in the cultivars Gravenstein, McIntosh, Ribston, and Wagener. The incidence and severity vary with the season, the orchard, and the tree. The disorder is associated with cool growing seasons and is likely to be significant after 6-7 months of cold storage at $0^{\circ} \mathrm{C}$ or in controlled-atmosphere storage at $3^{\circ} \mathrm{C}$. Like other forms of senescent breakdown, vascular breakdown intensifies when affected fruit is held at room temperature. In Australia, vascular breakdown has been observed in Cox's Orange Pippin and Sturmer that have been harvested late and stored at higher temperatures to avoid low-temperature breakdown.

For additional information, see Carne 1948; Carne and Martin 1938; Eaves and Hill 1940.

\section{Carbon dioxide injury}

Carbon dioxide injury may occur in fruit that is kept in controlledatmosphere storage, packed in gas-tight containers, transported in poorly ventilated vehicles, or given a postharvest treatment of $\mathrm{CO}_{2}$. The degree of injury is influenced by cultivar, temperature, concentration of $\mathrm{O}_{2}$ and $\mathrm{CO}_{2}$ in the atmosphere, duration of exposure to high levels of $\mathrm{CO}_{2}$, fruit maturity, and condition of the fruit. Apples exposed to high concentrations of $\mathrm{CO}_{2}$ accumulate acetaldehyde, ethanol, and acetic, malic, fumaric, citric, and succinic acids, perhaps as a consequence of reduced activity of glycolytic and Krebs cycle enzymes. However, whether any of these compounds are causal agents 
for $\mathrm{CO}_{2}$ injury is not known. Cultivars and individual fruits vary in their susceptibility to $\mathrm{CO}_{2}$ injury, possibly because of anatomical differences (size of intercellular spaces, rate of diffusion of gases within the apples) rather than biochemical differences. Carbon dioxide diffuses more slowly than oxygen in fruit tissue. Oxygen remains near ambient concentration in the apple, and the high affinity of cytochrome oxidase for oxygen may be one reason why low-oxygen injury rarely occurs in the presence of severe $\mathrm{CO}_{2}$ injury.

\section{External carbon dioxide injury}

External $\mathrm{CO}_{2}$ injury in apples (Figs. 10 and 11) appears as a brown or bronze roughened lesion in the skin, often well defined and partly sunken. The lesion resembles scald to some extent and occurs on the nonblushed skin areas of colored cultivars, such as Delicious. Injury in Golden Delicious is more prevalent in the calyx portion of the apple.

Low oxygen, immaturity, rapid establishment of $\mathrm{CO}_{2}$ levels before the fruit is cooled, and free moisture on the skin of the fruit are factors in $\mathrm{CO}_{2}$ injury of controlled-atmosphere-stored fruit. Injury usually occurs early in the controlled-atmosphere storage period, and neither the number of fruits nor the amount of surface affected increases with storage time. The effect of temperature has not been clearly determined, but higher temperatures (near $10^{\circ} \mathrm{C}$ ) appear to be less conducive to the development of the disorder. However, storing fruit at these temperatures is not recommended because of deterioration in quality.

\section{Internal carbon dioxide injury}

Internal carbon dioxide injury (Figs. 11 and 12), also called brown heart, is evident as brown necrotic cortex or core tissue, fairly well defined, firm, and moist but readily becoming dry as moisture is lost to surrounding healthy tissue. As desiccation continues, cavities develop, with light brown dry tissue forming the cavity walls. The external appearance of the fruit remains normal, except in severely injured fruit, where surface depressions may develop.

In some cultivars, tissue near the main vascular bundles is most susceptible. In others, small scattered zones of injury may be random. Injury ceases to progress when the causal conditions are removed.

In general, susceptibility to internal $\mathrm{CO}_{2}$ injury increases with fruit maturity and size, delayed cooling, low storage temperature, and low oxygen. Susceptibility to external and internal $\mathrm{CO}_{2}$ injury varies from tree to tree and can be affected by seasonal growing conditions.

Studies on Golden Delicious show no relationship between the mineral composition of the fruit and $\mathrm{CO}_{2}$ tolerance, but a positive correlation exists between the nitrogen content of fruit and the degree of injury. Cultivars sensitive to $\mathrm{CO}_{2}$ include Cortland, Cox's Orange Pippin, Fameuse, Golden Delicious, Granny Smith, Jonathan, 

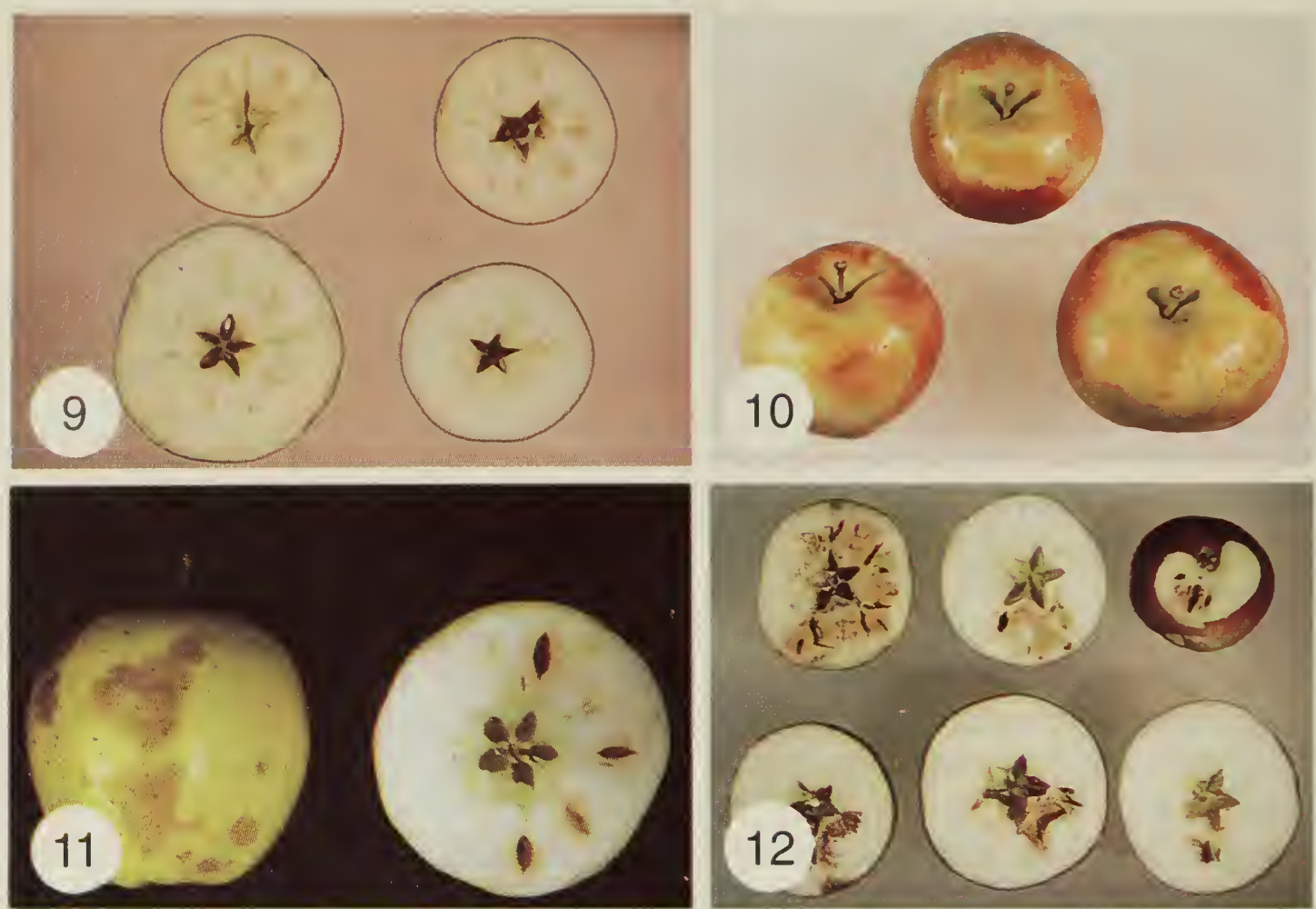

Fig. 9 Vascular breadkown (McIntosh)

Fig. 10 External carbon dioxide injury (McIntosh)

Fig. 11 External and internal carbon dioxide injury (Golden Delicious)

Fig. 12 Internal carbon dioxide injury (McIntosh) 
McIntosh, Northern Spy, Rome Beauty, and Wealthy, whereas Delicious and Spartan are less likely to develop either external or internal symptoms. Newtown Wonder can sustain injury in a $3 \% \mathrm{CO}_{2}$ atmosphere, but Worcester Permain tolerates up to $13 \% \mathrm{CO}_{2}$. Core browning, and in some cases internal browning, are influenced by $\mathrm{CO}_{2}$ concentration in the storage atmosphere.

For additional information, see Bramlage et al. 1977; Carne 1948; Faust et al. 1969; Handwerker 1979; Lau and Looney 1978; Lidster et al. 1990; Meheriuk 1979; Muraoka et al. 1985a, $1985 b$.

\section{Chemical injury}

During handling and storage, fruit may be exposed to chemicals that may lead to fruit injury if they are misused or if the fruit is sensitive. A phytotoxic vapor or solution enters the fruit through open lenticels, causing localized injury, the severity being dependent on concentration of the agent and length of exposure. Injury may also occur with substances precipitating out of solution (wettable powders or emulsions that break down), which then adhere to the surface of the fruit.

Current postharvest practices for apples include the use of scald-inhibiting chemicals, fungicides, calcium salts to control breakdown and bitter pit, detergents to clean fruit, and waxes to enhance appearance. The advantages of combining some of these materials in a single treatment are obvious, but the possibility of phytotoxicity is always a threat.

\section{Ammonia}

Ammonia is used as the refrigerant in many cold-storage facilities, but it injures fruit if it escapes into the storage room. The degree of injury depends on concentration of ammonia, length of exposure, fruit species, and cultivar (Figs. 13 and 14).

Olfactory detection occurs at about 50 parts per million, but 700 parts per million causes immediate eye irritation. Apples are injured by $0.2 \%$ ammonia.

The initial indication of injury is a change in pigmentation around the lenticels. Anthocyanins, the main contributors of red color in apples, change to dark blue as the $\mathrm{pH}$ of the cells becomes more alkaline in the presence of ammonia. Lenticels on the red skin areas of some apple cultivars may appear as prominent white spots surrounded by a dark ring 1-2 $\mathrm{mm}$ in diameter. In other apples, for example, McIntosh, ammonia may cause the red area of the skin to take on a purple cast, but the lenticels are highlighted only marginally.

If only an anthocyanin color change has occurred, the fruit may appear to have extensive injury, but it recovers quickly without permanent injury when placed in fresh air immediately. Injury in the vicinity of lenticels is usually permanent and assumes a circular sunken brown spot as dehydration proceeds in the injured cells. 
Yellow or orange apples have anthoxanthins in the skin, which turn brown or tan in the presence of ammonia. The color change is not as reversible as that of anthocyanins. Because most apples are sensitive to ammonia vapors, ammonia detectors are recommended for storage rooms.

For additional information, see Brennan et al. 1962; Dewey 1952; Pierson et al. 1971; Ramsey and Butler 1928.

\section{Calcium salts}

Calcium salts (calcium chloride or calcium nitrate) are often used in preharvest sprays or postharvest dips to control bitter pit and breakdown in apples. Calcium chloride is less likely to cause injury than calcium nitrate, but tolerance depends on concentration, cultivar, adjuvants, method of treatment, and growing conditions. Injury from calcium solutions in dips often occurs at the lenticels and is probably caused by plasmolysis of cells in the presence of high salt concentrations. The tissue darkens through oxidative reactions and becomes depressed from dehydration. In other instances, injury may develop on the sepals and skin in the calyx basin. Desiccation of damaged tissue often results in small cracks around the calyx, particularly in the calyx basin; exposed tissue in the cracks is vulnerable to rots (Fig. 15). When calcium solutions are introduced into the fruit by vacuum or pressure, the damage to cultivars with open calyx tubes or permeable skin may be extensive, externally and internally. Golden Delicious (Fig. 16), which sometimes have an open calyx as well as permeable skin, are subject to injury by vacuum or pressure calcium treatment, but cultivars such as McIntosh, Delicious, Spartan, and Cox's Orange Pippin are less prone to damage by these procedures. Growing conditions appear to have a strong influence on whether apples have an open calyx.

Foliar applications of $\mathrm{CaCl}_{2}$ can be phytotoxic; treated Golden Delicious in South Africa develop necrotic spots during subsequent storage. Late sprays increase the potential for such injury. High concentrations of $\mathrm{CaCl}_{2}(4 \% \mathrm{w} / \mathrm{v})$ induce red halos around the lenticels in Golden Delicious. Evidence indicates a greater susceptibility of fruit to calcium injury when growing conditions are cool and dull and if fruit within the tree is poorly colored.

Adding ethoxyquin or benomyl to a calcium solution may increase the risk and severity of phytotoxicity. Diphenylamine, however, appears to have a beneficial role in the uptake of calcium. Lecithin has a synergistic effect in calcium chloride solutions on the control of calcium-related disorders. Calcium levels in the flesh can be significantly increased when xanthan gum is added to the calcium solutions. Gums increase the viscosity of the solution and enable a thicker layer of solution to adhere to the skin of the fruit. Delicious apples dipped in a solution of $\mathrm{CaCl}_{2}$, ethoxyquin, and guar gum develop severe discoloration of the skin during subsequent storage. It is 
therefore imperative to evaluate any postharvest dip solution for efficacy and phytotoxicity.

For additional information, see Hardenburg and Anderson 1979; Johnson and Marks 1981; Johnson et al. 1980; Lidster 1983; Terblanche et al. 1971.

\section{Diphenylamine}

Scald control with diphenylamine (DPA) usually causes more injury to fruit than ethoxyquin, particularly when wettable powder preparations are used. DPA may produce dark skin lesions similar to those caused by ethoxyquin (Fig. 17). In addition, the DPA solutions may break down, and crystals can precipitate on the fruit, causing skin injury while the fruit is in cold storage. Injury consists of a black lesion on the skin and in some instances may penetrate into underlying tissue. In other instances, injury may be accompanied by a bluish discoloration of cortical tissue remote from the skin lesion. Because Golden Delicious may develop a bluish discoloration of the skin when exposed to DPA, ethoxyquin is preferred for scald control of this cultivar. DPA appears to be more compatible than ethoxyquin with calcium salts in postharvest treatments and has been reported to enhance calcium effects on breakdown and bitter pit. Safe use of this combination is probably influenced by cultivar tolerance as well as by concentration of calcium salt and should not be used until limitations are established.

For additional information, see Eksteen 1980; Nardin and Trevisani 1986; Pierson and Schomer 1968; Scott and Wills 1975.

\section{Ethoxyquin}

Fruit injury is likely to occur in bins that retain liquid in the bottom portion after drenching. The ethoxyquin becomes more concentrated as the water evaporates during subsequent cold storage, and fruit in contact with this liquid develops a blackened ring of necrotic tissue. Tissue in the centre of the ring may be unaffected because firm contact with the bottom of the bin prevents the liquid from reaching it (Fig. 18). No injury from liquid retained in the calyx or stem cavities, or at contact points between apples, has been reported to date. Severe discoloration occurs in Delicious apples dipped in a solution of ethoxyquin, $\mathrm{CaCl}_{2}$, and guar gum.

For additional information, see Meheriuk 1981; Porritt and Meheriuk 1968; Sharples and Johnson 1976.

\section{Freon}

In addition to ammonia, several chlorofluorocarbons (CFCs), known commercially by various names including Arcton, Freon, Frigen, and 
Genetron, are used as refrigerants, in particular CFC-12. These refrigerants are clear, colorless gases that have a slight sweetish odor if present in high concentrations. Although damage to apples and pears by any CFCs has not been reported previously in the literature, injury has been observed in stored McIntosh apples that were accidentally exposed to CFC-12. It is therefore possible for CFC-12 escaping into the storage room to injure the fruit, depending on the concentration and the exposure time.

As CFC-12 penetrates through the skin it kills the cells in the cortex, starting with the subepidermal cells first (Fig. 19). As these cells die the cellular contents leak out, and the tissue darkens through oxidation and collapses from dehydration. The damaged tissue has a dry corky texture. Desiccation of the damaged tissue can be seen as slightly depressed areas on the fruit surface. Removing the CFC-12 through ventilation of the storage should stop further damage to the fruit.

\section{Core browning}

Core browning, also called brown core, brown heart, or core flush, is a storage disorder of apples characterized by diffuse browning of the flesh next to the carpels, with no clear distinction between normal and affected tissue (Fig. 20). In some cultivars the disorder is first evident as a pinkish or yellowish discoloration. Core browning in susceptible fruit appears after 3-4 months in cold storage and rapidly becomes more extensive when the fruit is removed to warmer locations.

Core browning is associated with storage temperatures of -0.5 to $3.5^{\circ} \mathrm{C}$ but may occur on occasion at temperatures of up to $4.5^{\circ} \mathrm{C}$. A delay in cooling the fruit after harvest sometimes reduces the amount of core browning, but delays may adversely affect the storage quality of the fruit. Core browning in Granny Smith apples can be reduced by lowering the temperature in stages during the first few weeks of storage. Interim warming during storage is an effective treatment for preventing core flush.

Factors other than temperature can also influence the susceptibility of fruit to core browning. The disorder is likely to be more prevalent in fruit that is high in nitrogen, large, shaded on the tree, harvested after an extended period of cloudy, wet, or cool weather, or irrigated frequently. Advanced maturity tends to reduce the incidence of the disorder, but Lombart's Calville develops more core flush with late harvests. Core flush is reduced by delayed storage, $\mathrm{P}$ sprays, $\mathrm{Ca}$ sprays, dips in ethoxyquin and diphenylamine, waxing, and heat treatments before storage. In controlled-atmosphere storage, a higher concentration of $\mathrm{CO}_{2}$ is likely to increase core browning, particularly if oxygen is also high. Low-oxygen storage $(<2 \%)$, however, is one of the most effective treatments for controlling core flush.

Either an excess or a deficiency of boron can induce core browning. Core browning caused by boron deficiency differs from ordinary core browning by the presence of scattered corky areas in other parts of the 

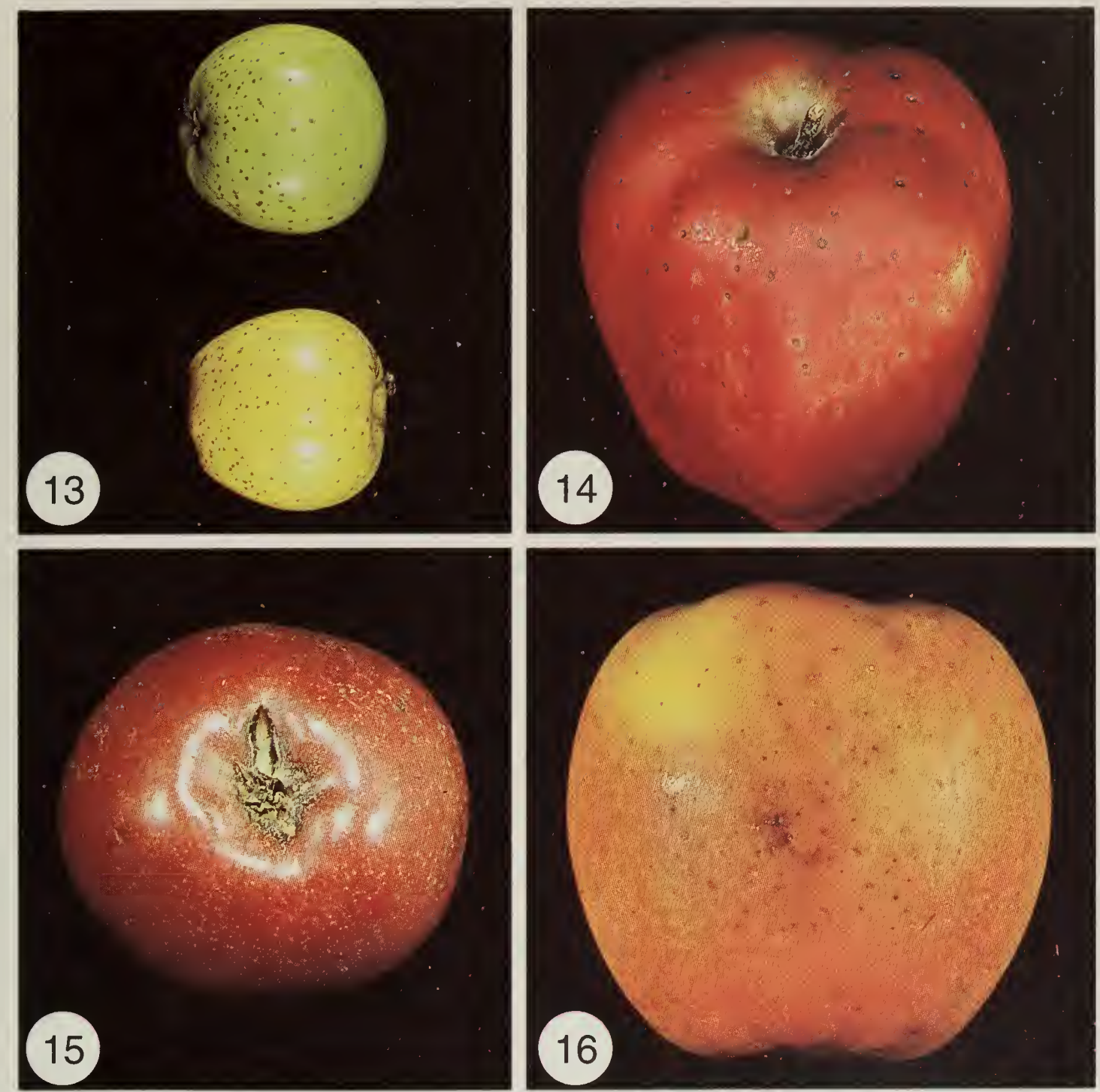

Fig. 13 Ammonia injury (Golden Delicious)

Fig. 14 Ammonia injury (Delicious)

Fig. 15 Calcium chloride injury (Spartan)

Fig. 16 Calcium chloride injury (Golden Delicious) 
flesh. Excessive boron, however, may cause symptoms indistinguishable from ordinary core browning.

Morphological studies show cell volumes of susceptible and nonsusceptible cultivars to be comparable in size. Core flush in Cox's Orange Pippin correlates well with percentage of dry matter from late August to harvest. Higher levels of $\mathrm{Cu}$ and $\mathrm{Mg}$ have been reported for core flush tissue in Spartan.

Apples susceptible to core browning include Baldwin, Granny Smith, Gravenstein, Grimes Golden, McIntosh, Newtown, and Rhode Island Greening. Less susceptible cultivars include Cox's Orange Pippin, Delicious, Gloster, Golden Delicious, Jonathan, Lombart's Calville, Rome Beauty, Spartan, and Sturmer.

Core browning in McIntosh is often accompanied by browning of the skin and underlying flesh in the stem cavity (Fig. 21). The two conditions appear to be related, because they are both caused by the same factors during growth and storage, and both increase in severity when the fruit is transferred to room temperature. Fruit from the terminal position on the spur and fruit with shallow stem cavities is more susceptible to stem cavity browning than is other fruit.

For additional information, see Carroll 1968; Chiu 1984; Dalton et al. 1982; Fidler and North 1965; Little et al. 1985; Lougheed et al. 1978; Pierson et al. 1971; Scott and Wills 1976a, 1976b; Sharples and Johnson 1987.

\section{Flesh browning}

Flesh browning, often referred to as internal browning, is a diffuse browning of the flesh of the apple, without any definite outline of the affected tissue. It may affect the outer flesh, the tissue around the core, or both areas. In more advanced stages, browning may encompass most of the internal tissue of the fruit (Fig. 22). With flesh browning, the vascular elements usually appear normal, in contrast to the brown vascular bundles observed in freezing or breakdown. The external appearance of the apple is not likely to disclose the presence of the disorder, and the texture of the fruit, except in the most advanced cases, is not altered. Microscopic examination shows dead brown cells scattered among apparently healthy cells.

The disorder in Newtown apples usually begins in tissue adjacent to the vascular bundles and is likely to be most evident in a transverse section at the junction of the stem and the carpel. Flesh browning in Newtown and other cultivars is primarily a low-temperature abnormality that develops during storage at temperatures of less than $3^{\circ} \mathrm{C}$. It may become prominent after $2-3$ months of cold storage, depending on cultivar susceptibility, and continues to progress after the fruit is removed from storage.

Apples grown in cool temperatures are predisposed to internal browning. Fruit from shaded parts of the tree is more susceptible than that from exposed areas. No consistent relationship is apparent between the disorder and the sugar or acid levels in the fruit, but the 
disorder is likely to be more extensive in large fruit, in fruit from lightly cropped trees, and in fruit from trees that have a high nitrogen level or low vigor. Late harvesting and delayed cold storage increase the incidence of the disorder.

An increase in cell permeability (measured by electrical resistance) has been found to precede the appearance of flesh browning. Furthermore, increased air movement, ventilation of the fruit, or the use of oiled wraps reduce the disorder, thus implicating a volatile substance as a causal factor.

Flesh browning occurs in Baldwin, Boskoop, Cox's Orange Pippin, Delicious, Elstar, Jonagold, Jonathan, Lombart's Calville and Rhode Island Greening. In Jonathan and Delicious, flesh browning is sometimes associated with water core. In Jonathan and Cox's Orange Pippin, the browning of cortex tissue that occurs in storage at low temperatures may, in fact, be the early stages of low-temperature breakdown. Results with Delicious show that flesh browning is reduced by early harvest, by higher storage temperatures, by calcium dips, and by reduced levels of $\mathrm{CO}_{2}$ in controlled-atmosphere storage. In suppressing flesh browning, studies with Jonathan show the importance of avoiding late harvesting and of limiting the $\mathrm{CO}_{2}$ concentration to about $1 \%$.

The effects of fruit size, maturity, volatile substances, calcium, and storage conditions on both internal browning and low-temperature breakdown are similar enough to suggest that both disorders are manifestations of a common metabolic disturbance.

For additional information, see Godwin and Ehlermann 1983; Henze 1971; Meheriuk et al. 1984; Overholzer et al. 1923; Schouten 1986; Winkler 1923.

\section{Freezing injury}

Improved refrigeration facilities in storage and in transit have reduced or eliminated freezing damage to fruit after harvest (Fig. 23). Temperatures below freezing, however, occur in some seasons and localities before the harvest is completed. Both temperature and duration of exposure determine the extent of damage. Other factors that influence freezing are rate of air movement, degree of protective cover within the tree, height within the tree, and fruit size (large fruit has a higher heat content). Ice formation in intercellular spaces gives tissue a water-soaked appearance but does not cause tissue injury. Such fruit, however, is likely to have a higher respiration rate, to be more susceptible to decay, to soften more rapidly than normal fruit, and to become mealy. More extensive freezing causes large ice crystals to form, which rupture cell membranes and walls and result in profuse enzymic browning and ultimate cell death. When it is thawed, severely frozen fruit is brown, soft, and wet. Moderate freezing injury may kill vascular elements, which become prominently brown in contrast to less damaged cortical tissue. Tests on Delicious apples show two freezing points (exotherms) at -2.1 and $-4.7^{\circ} \mathrm{C}$. Freezing through exotherm 1 


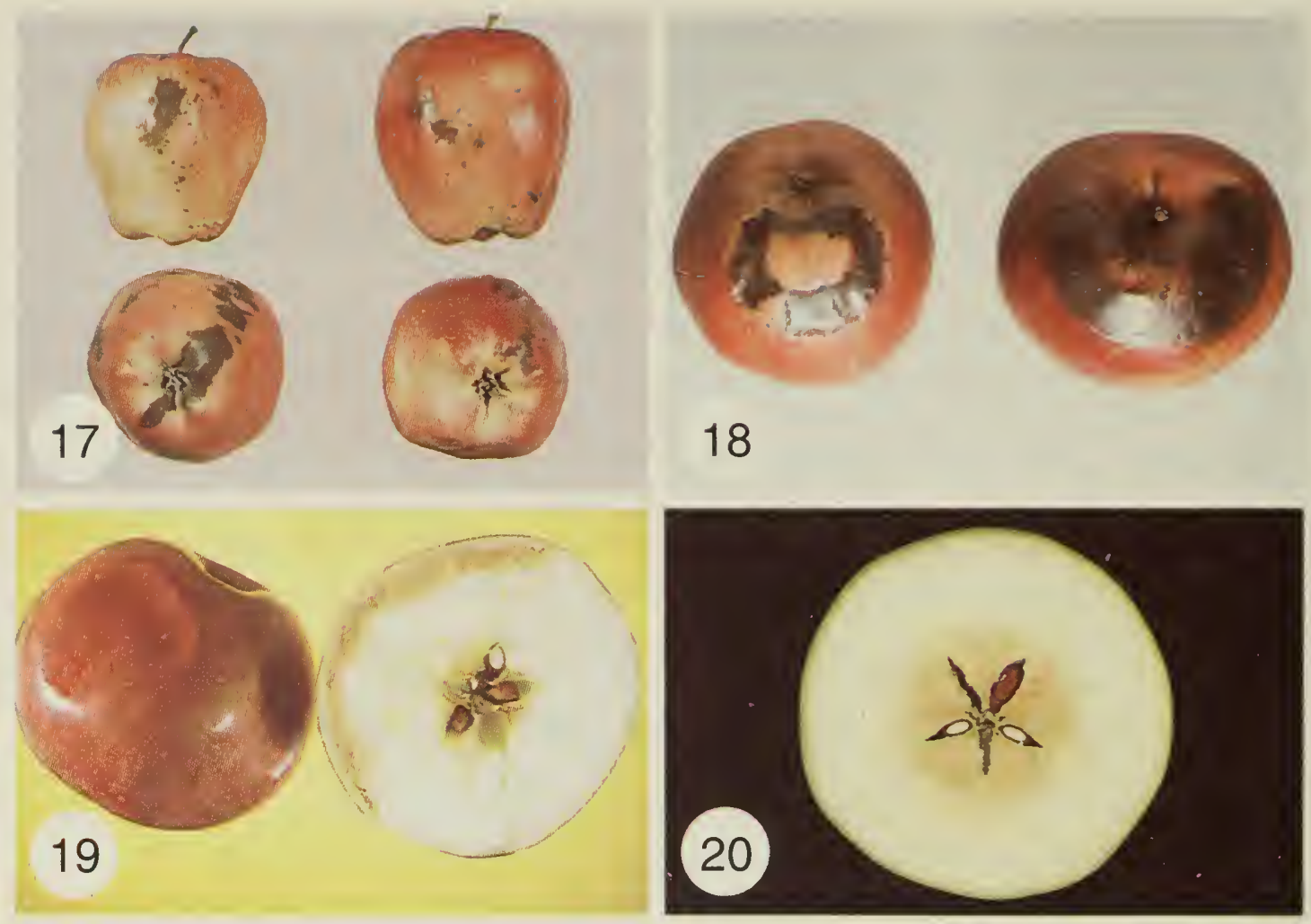

Fig. 17 Diphenylamine injury (Delicious)

Fig. 18 Ethoxyquin injury (Winesap)

Fig. 19 Freon injury (McIntosh)

Fig. 20 Core browning (Newtown) 

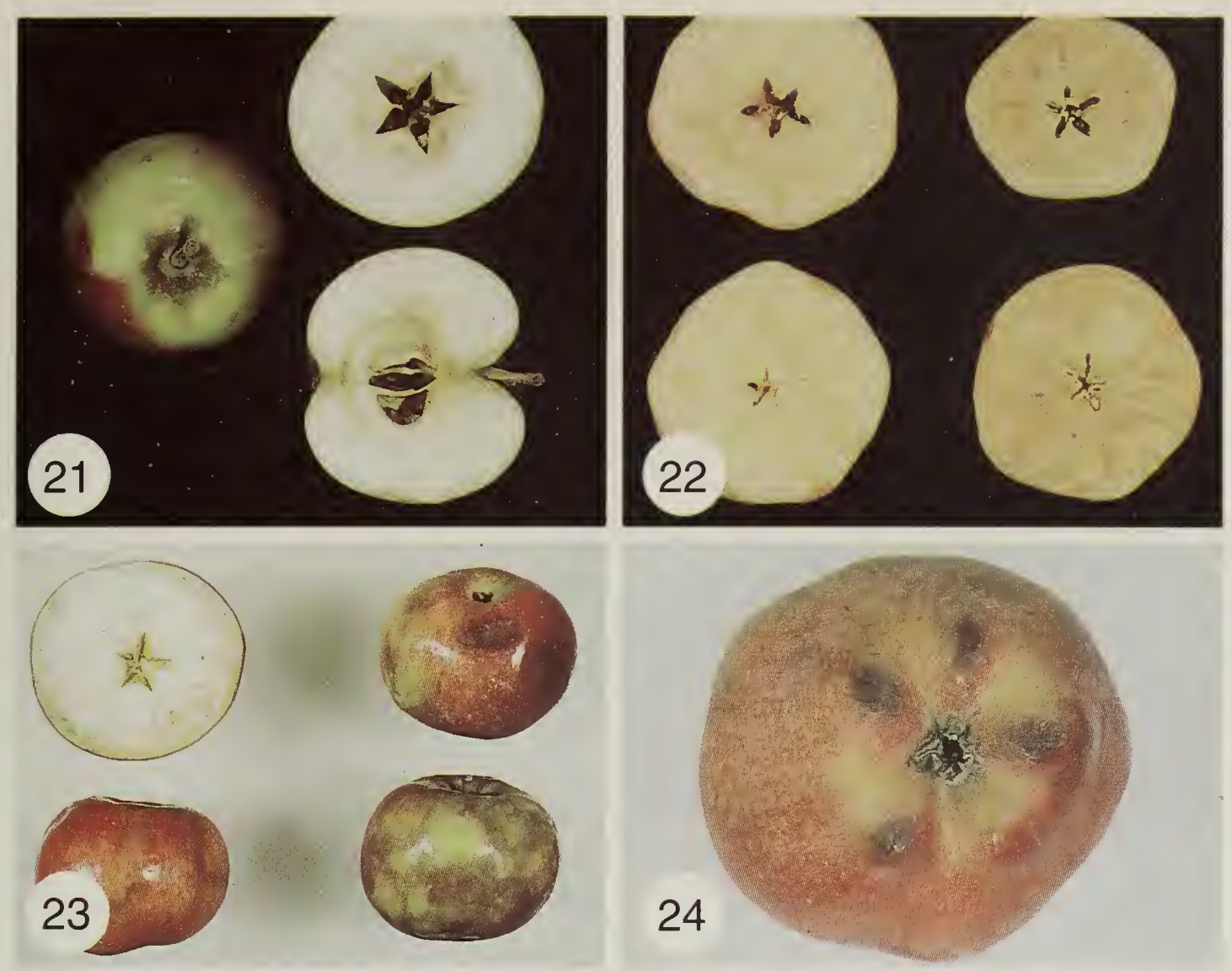

Fig. 21 Core and stem-end browning (McIntosh)

Fig. 22 Flesh browning (Delicious)

Fig. 23 Freezing injury (McIntosh)

Fig. 24 Hot water injury (Delicious) 
involves ice formation in the intercellular spaces; freezing through exotherm 2 causes ice formation within the cells.

Minor freezing injury on the surface of the fruit results in a brown discoloration of skin, often accompanied by water-soaked areas with irregular outlines. During storage the lesion may remain intact or become sunken, depending on the extent of injury to the subepidermal tissue, which loses moisture more readily after freezing damage. Internal freezing injury results in brown discoloration of injured tissue, which, through desiccation, may develop cavities in the damaged areas during subsequent cold storage. Skin injury and internal injury may occur independently or coincidentally in the same fruit. The volume of a frozen apple can be reduced by as much as $10 \%$, and the skin becomes noticeably wrinkled. Most of the original volume, however, is recovered on thawing. Fruit that is suspected of being frozen should be moved carefully, because bruising damage is intensified in frozen tissue. Also, movement may induce ice formation in supercooled tissue. When fruit thaws, bruised areas are likely to be conical, with the apex extending deep into the flesh below the point of impact.

Thawing frozen tissue at various rates, within a range of $0-20^{\circ} \mathrm{C}$, has little effect on the extent of injury. If fruit remains frozen for a longer period because thawing time is extended to days or weeks, freezing damage may be increased. Fruit that is thawed by water immersion can imbibe enough water to split open. There is evidence that apples frozen on the tree suffer less residual damage than fruit detached from the tree and exposed to the same conditions.

The average freezing point for apples, determined by many tests on numerous cultivars, is $-2^{\circ} \mathrm{C}$, with a range of -1.4 to $-2.3^{\circ} \mathrm{C}$. Apples can usually sustain temperatures of $1-2^{\circ} \mathrm{C}$ below their freezing point for short periods ( $24-48 \mathrm{~h}$ ) without any visual injury after thawing. There is no evidence that the freezing point changes during prolonged storage. Freezing points are influenced by the amount of dissolved substances in the cytoplasm (e.g., sugars, organic acids).

Frozen fruit that shows no apparent injury should be marketed promptly or processed soon after the freezing was noted.

For additional information, see Bir and Bramlage 1973; Bir et al. 1973; Carne 1948; Carrick 1924, 1928; Fisher et al. 1953; Simons and Doll 1976; Smock 1970, 1972.

\section{Friction marking}

Apples are quite resistant to friction marking, but marking does occur when fruit is subjected to intensive movement in loosely filled cartons during transit of the commodity. The symptoms are similar to those exhibited by pears, in that the skin turns dark brown to black. Oxidation of phenolics in the skin causes the discoloration. For a more complete discussion of friction marking, consult the same topic under pears, a commodity much more prone to the malady. 


\section{Heat injury}

\section{Hot air or hot water}

Certain postharvest treatments can result in heat injury to apples (Figs. 24 and 25). Hot-water treatment can be used to inhibit scald development and fungi growth, but the temperature and exposure time must be carefully controlled to avoid injury. Heat damage has occurred on apples from the hot-water wash used before waxing and from the hot air used in drying the waxed fruit. Contact with water at $55^{\circ} \mathrm{C}$ for $30 \mathrm{sec}$ can cause latent damage to the skin of apples. The injury appears after several weeks of storage as a diffuse browning of the skin, similar to common scald and, as in scald, the unblushed portions are preferentially affected. Prominent calyx lobes of Delicious apples are quite susceptible because they rise in temperature more quickly than the rest of the apple when exposed to hot air or hot $\left(38-40^{\circ} \mathrm{C}\right)$ water. Apples given heat treatment before storage retain quality more effectively and have a reduced incidence of disorders. However, exposure to $46^{\circ} \mathrm{C}$ for $24 \mathrm{~h}$ or to $42^{\circ} \mathrm{C}$ for $48-96 \mathrm{~h}$ results in patchy skin browning and flesh browning near the vascular bundles.

For more information, see Klein and Lurie 1992; Maxie et al. 1974; Porritt and Lidster 1978.

\section{Sunscald}

A common form of heat injury is sunscald, which appears as a bleached or bronzed area or sometimes as a blackish area on the exposed surface of red fruit (Fig. 26). On yellow or green cultivars, such as Newtown, Golden Delicious, and Granny Smith, sunscald may cause bronzing or a reddish blush. In most instances the heat-damaged area becomes considerably darker during and after removal from storage. Injury barely apparent at harvest may become quite obvious after several months of cold storage.

Damage from sunscald may be confined exclusively to the skin or it may affect cortex tissue to varying depths. Injured tissue is brownish, usually very firm, and bitter tasting - a consequence of high levels of phenolics in the tissue. Superficial scald can still develop in sunburned apples, and scald-susceptible cultivars should still be treated with diphenylamine or ethoxyquin. In extreme cases, heat damage turns the flesh brown, which may sometimes result in a watersoaked appearance. In this fruit the affected area is sunken and brown. This form of damage occurs during a period of unusually hot weather following cool or moderate conditions, particularly when accompanied by water stress (inadequate rainfall or irrigation).

The temperature of the exposed side of an apple may be as much as $18^{\circ} \mathrm{C}$ above ambient air temperature and $8-9^{\circ} \mathrm{C}$ warmer than the shaded side of the fruit. Apples develop a tolerance for high temperature but can be damaged by a sudden hot spell, by exposure to the sun of fruit on shaded branches that are soon weighted down by 
a heavy crop load, or by exposure to the sun after harvest. Judicious tree training should help to reduce the incidence of sunburn.

For additional information, see Bergh et al. 1980; Brooks and Fisher 1926; Carne 1948; Meheriuk and Porritt 1968.

\section{Jonathan spot}

Jonathan spot is a disorder affecting the skin of the apple. The disorder appears as a circular spot, $2-4 \mathrm{~mm}$ in diameter, brownish or almost black when associated with red skin, and usually more prevalent on the highly colored part of the apple (Figs. 27 and 28). On green or yellow skin, the spots are lighter. Occasionally, the symptoms occur before harvest on well-matured fruit, but they usually appear after several months of storage, during which time the spots increase in size and sometimes coalesce to produce an irregular outline. The spots often, but not always, occur around the lenticels. Spotting that is confined to the lenticels is considered by many physiologists to be another form of Jonathan spot. Lesions sometimes become partly sunken, particularly if fungal infections are present. Lesions rarely affect hypodermal tissue.

Although the disorder is called Jonathan spot because of its frequent occurrence in this cultivar, it has also been observed in Golden Delicious, Idared, Rome Beauty, Wealthy, and Winesap.

Lenticel spot, which resembles Jonathan spot, is always associated with lenticels and is often caused by chemicals that come in contact with the fruit. These chemicals include ammonia, sulfur dioxide, urea formaldehyde (found in fruit trays), volatile substances from ripe fruit, ethylene, or salts used in dump tanks.

The specific cause of Jonathan spot is not known, but advanced maturity, highly colored fruit, delayed cooling of harvested fruit, and high storage temperatures are factors that increase its incidence. Ultraviolet light can also induce the disorder. The disorder does not appear to be closely related to the chemical composition of the fruit, but an increase in its calcium level by preharvest sprays or postharvest calcium dips is effective in reducing it. The most successful preventive measure, in addition to harvesting fruit at the appropriate maturity and ensuring adequate handling and storage procedures, is controlledatmosphere storage. Carbon dioxide levels as low as $0.7 \%$ in the storage atmosphere prevent Jonathan spot.

For additional information, see Balazs and Toth 1974; Bangerth 1973; Fukuda 1982; McColloch et al. 1965; Padfield 1969; Pierson et al. 1971; Richmond et al. 1964; Simons 1968b; Tomana 1963.

\section{Low-oxygen injury}

Low-oxygen injury may become a more prevalent disorder as storage atmospheres below $2 \% \mathrm{O}_{2}$ are adopted by industry. Critical oxygen levels differ among apple cultivars; Delicious are tolerant of 


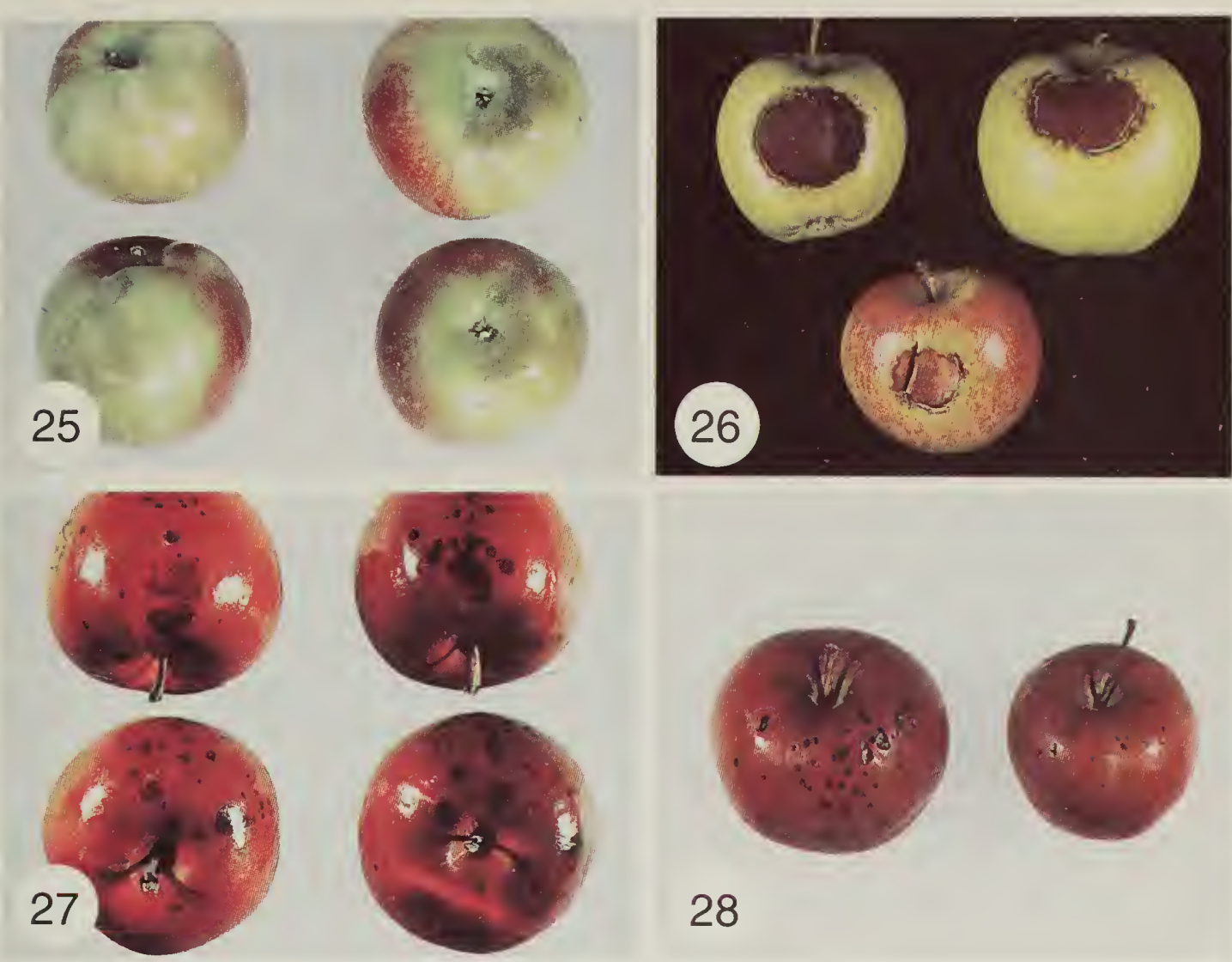

Fig. 25 Hot water injury (McIntosh)

Fig. 26 Sunscald injury (Golden Delicious, Shamrock, and Fuju)

Fig. 27 Jonathan spot (Jonathan)

Fig. 28 Jonathan spot (Winesap) 
atmospheres below $1 \% 0_{2}$, whereas McIntosh in some growing areas are injured in atmospheres below $2 \% \mathrm{O}_{2}$. Reduced oxygen levels render pome fruits more sensitive to $\mathrm{CO}_{2}$, and therefore narrow limits may have to be implemented for $\mathrm{CO}_{2}$ to avoid $\mathrm{CO}_{2}$-related problems. Pears, for instance, tolerate little $\mathrm{CO}_{2}$ in the presence of $1 \% \mathrm{O}_{2}$, and therefore concentrations of $\mathrm{CO}_{2}$ are kept close to $0 \%$. It is not certain whether ethanol or a product of ethanol metabolism is the causal factor of lowoxygen injury.

Studies in England have shown that apples exposed to short periods of reduced oxygen supply can recover with aeration if the alcohol concentration in the tissue does not exceed $120 \mathrm{mg} / 100 \mathrm{~g}$ of fresh weight. Higher alcohol concentrations than this amount render the fruit unfit for sale because of an unacceptable taste. Visible injury is usually not present. Anaerobic conditions $\left(<1 \% \mathrm{O}_{2}\right)$ for 4 days or more with Cox's Orange Pippin apples result in irreparably damaged fruit. Red Delicious apples, on the other hand, require 8-10 weeks of storage in $0 \% \mathrm{O}_{2}$ before injury is evident. McIntosh is highly susceptible to low-oxygen injury, whereas Northern Spy, Empire, and Spartan rarely show symptoms.

Low-oxygen injury varies with cultivar, oxygen concentration, length of exposure, and temperature. Injured apples develop dark brown water-soaked lesions in the skin, which may extend into subepidermal tissue. The lesions have definite margins, resemble soft scald, and are present on the blushed and nonblushed sides of the apple. Soft scald, however, tends to be confined to the green or nonblushed side (Fig. 29). As the severity of the injury increases, varying amounts of cortex and core tissue may become brown, moist, and water-soaked.

Other symptoms of low-oxygen injury include purpling and the development of brown, corky tissue below the skin (Fig. 30) or throughout the cortex. The corking disorder is exacerbated by advanced maturity and low storage temperatures. Brown corky tissue can also develop in late-stored Cox's Orange Pippin apples (Fig. 31). The lesions occur in the inner and outer cortical regions, mostly in the stem half of the fruit. The incidence of the disorder is aggravated by low-oxygen atmospheres of $1-1.25 \%$. Low-temperature breakdown, core flush, and core browning can be accelerated in low-oxygen atmospheres. The effects of low-oxygen injury are mitigated by high humidity in the storage atmosphere. McIntosh apples stored in low oxygen sometimes develop water-soaked bruiselike lesions, and the fruit may have a purplish cast in the red areas of the skin.

For additional information see Chen et al. 1985; Fidler and North 1971; Lau et al. 1986; Lidster 1990; Nichols and Patterson 1987; Patterson and Nichols 1988; Sharples 1982; Thomas 1929.

\section{Russet}

Russet is a condition in which phellogen (cork) tissue appears on the surface of an apple. The disorder may be of a slight nature (Fig. 32) or one in which the entire surface is covered by a network of corky tissue 
(Fig. 33). Thin cuticles, irregular cell division, and fruit cracking are factors involved in the development of russet. The disorder is initiated 11-30 days after the petals fall.

High temperatures at night and high humidity are conducive to russet initiation. Mechanical injury from frost, hail, or wind also predisposes the fruit to russet. Mineral content does not appear to influence the disorder. Russet is more prevalent on lateral than on terminal fruit, on exposed than on shaded fruit, and on fruit from lower-altitude growing areas. Russeted fruit has higher levels of sucrose, glucose, total sugars, and acids, but phenolic concentration is lower than in nonrusseted fruit. Leachates of the flowers of apples cause russet, and it is thought that rainfall leaches these substances from flowers and deposits them on the fruit surface.

Russet may also be genetic in nature, and cultivars such as Golden Russet apple are often heavily russeted by harvest time. Some fungicidal and chemical sprays (e.g., $\mathrm{ZnSO}_{4}$ ), as well as spray surfactants, can be phytotoxic and cause russeting of fruit. A severe case of powdery mildew can also cause russet on apples (Fig. 34). The powdery mildew fungus produces obvious leaf symptoms that point to its probable culpability as the principal cause of russeted fruit.

Preventive procedures include the use of dimethoate, wettable sulfur, silicone preparations, and fungicides as foliar sprays. The preferred treatment is $\mathrm{GA}_{4+7}$, applied at 5-10-day intervals during full bloom. Gibberellic acid encourages elongation of epidermal cells, which are better able to withstand internal pressures within the fruitlet. The gibberellin is not registered for russet control in North America. Russet is often reported in Cox's Orange Pippin, Discovery, Dunn's Seedling, Golden Delicious, Newtown, Rome Beauty, Stark, and Stayman's Winesap. However, some strains of Golden Delicious are russet-free.

For additional information, see Ashizawa et al. 1984; Cappelini 1970; Eccher 1986; Faust and Shear 1972; Kanbe et al. 1973; Noga and Wolter 1990; Simons and Chu 1978; Taylor and Knight 1986; Vries 1968; Walther 1966; Watanabe 1969.

\section{Scald}

Storage scald, also called common scald and superficial scald, is often confined to the skin of the fruit. Oxidation products of a naturally occurring terpene, $\alpha$-farnesene, are now suggested as the cause of scald. Free radicals react with the $\alpha$-farnesene to produce conjugated trienes, but the mechanism by which they induce scald in the epidermal cells is not known.

After several months of cold storage, the disorder may appear as a diffuse browning of the skin, somewhat roughened in severe cases, which becomes more extensive after a few days at room temperature (Figs. 35 and 36). On red cultivars the scald lesion is often confined to the unblushed areas of the skin. Brown scald-like spots around the lenticels alone or accompanying the usual form of scald have been referred to as lenticel scald, which responds to commercial control procedures. Histological studies indicate a relationship of dense 

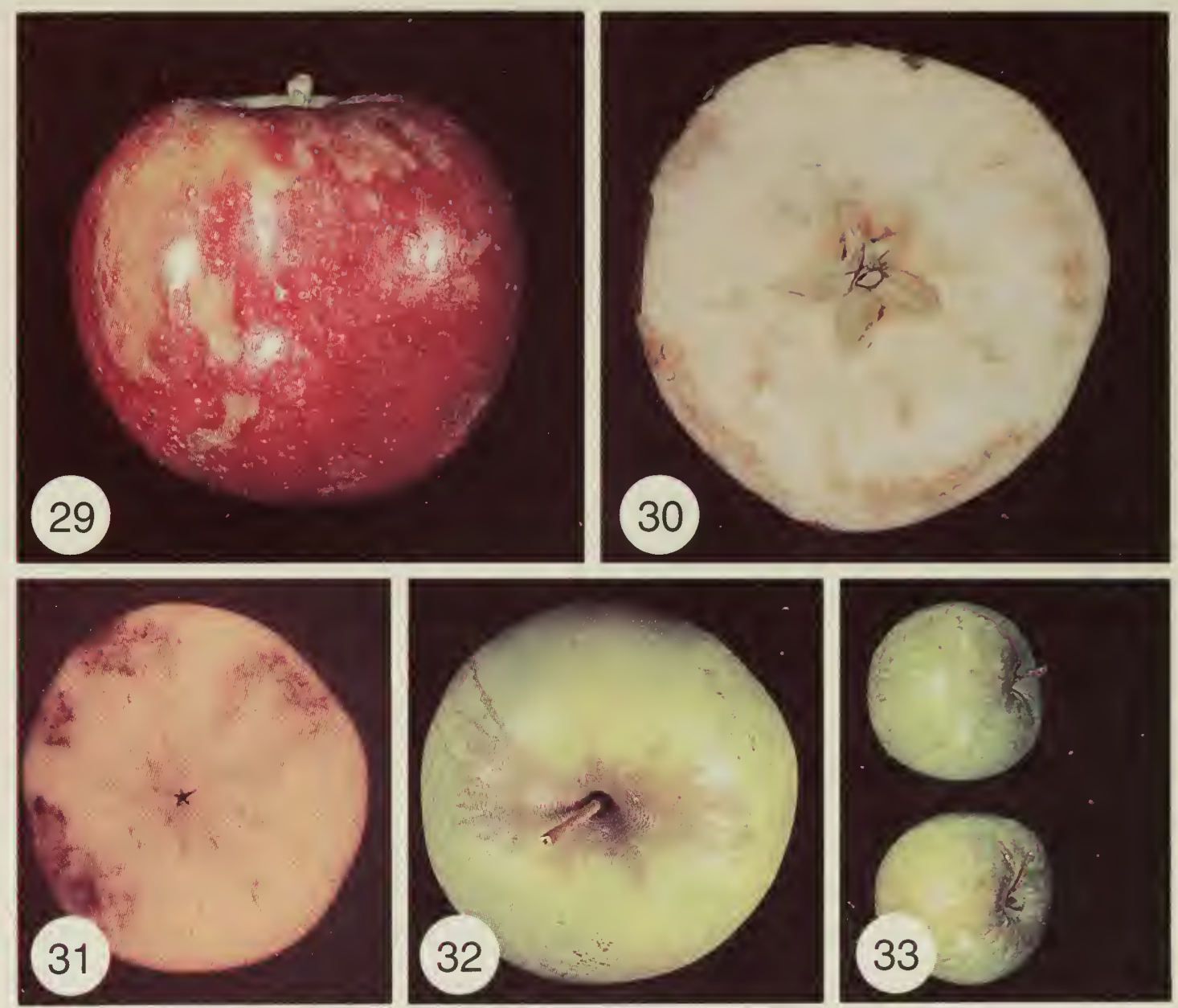

Fig. 29 Low-oxygen injury (McIntosh)

Fig. 30 Corky flesh browning (McIntosh)

Fig. 31 Late-storage corking (Cox's Orange Pippin)

Fig. 32 Russet (Golden Delicious)

Fig. 33 Russet (Golden Delicious) 

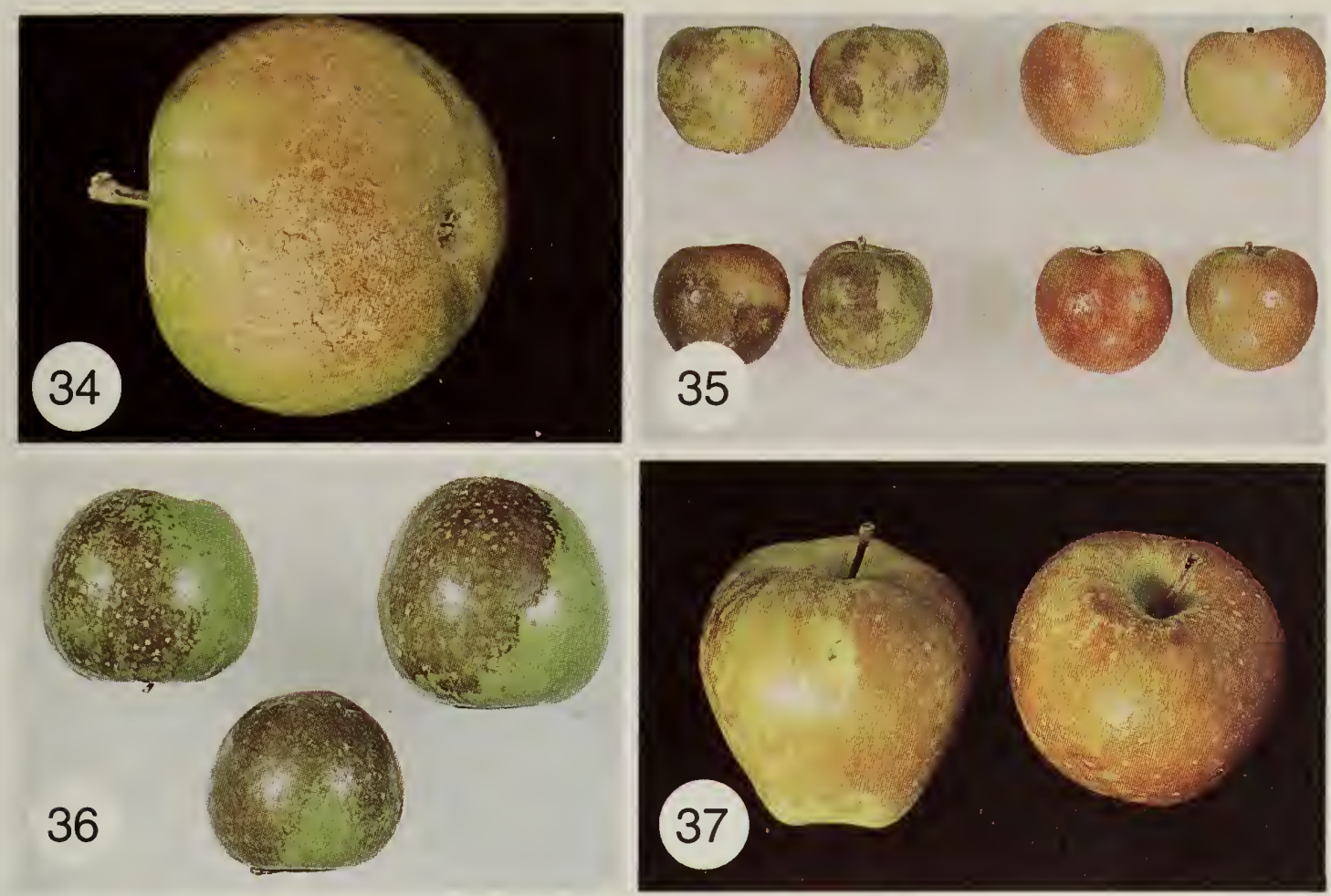

Fig. 34 Russet caused by severe powdery mildew (Golden Delicious)

Fig. 35 Scald (Stayman)

Fig. 36 Scald (Granny Smith)

Fig. 37 Senescent scald (Golden Delicious) 
material in the hypodermal vacuoles to scald development. Cells in scald-prone apples stain more intensely with methylene blue before the onset of the disorder than do cells in scald-resistant apples. Susceptibility to scald may be influenced by the concentration of naturally occurring antioxidants in the skin. The number of degreehours below $10^{\circ} \mathrm{C}$ before harvest is a good predictor of scald potential in apples. Higher activities of lipoxygenase and polyphenoloxidase and lower peroxidase activity have been observed in scald-susceptible apples. Peel flavonoids also appear to be associated with scald development.

The severity of the disorder is influenced by cultivar, season, cultural practices, and postharvest conditions. An apple cultivar may develop scald in one locality but not in another. Factors that increase the severity of the disorder include immaturity, high fruit nitrogen, low fruit calcium, warm preharvest weather, delayed cold storage, high storage temperatures, high relative humidity in storage, restricted ventilation, extended storage periods, and (in CA storage) slow oxygen reduction and high oxygen concentration. The reduction of scald associated with increased air movement and ventilation in storage is now thought to result from a lower concentration of $\alpha$-farnesene in the skin. Other effective treatments are interim warming during storage, low oxygen, hot water dips, ethrel sprays, calcium sprays, and fruit coatings such as lecithin. Fruit wraps containing $15 \%$ mineral oil have been replaced by scald-inhibiting chemicals. One of two antioxidants, diphenylamine or ethoxyquin, is applied after harvest; both are widely used around the world. Also effective, but at much higher concentrations, are butylated hydroxyanisole and butylated hydroxytoluene.

Scald-control measures should be initiated within 1-6 weeks of harvest to achieve good control of the disorder. An exception is senescent scald, which occurs on some well-matured Golden Delicious after a long period of storage (Fig. 37). Ethoxyquin prevents senescent scald, if applied within 17 weeks of harvest.

Cultivars susceptible to scald include Baldwin, Ben Davis, Cleopatra, Cortland, Delicious, Granny Smith, Rhode Island Greening, Rome Beauty, Stayman, Wagener, Winesap, and York Imperial. Golden Delicious, Jonathan, McIntosh, Newtown, Northern Spy, and Spartan are less susceptible cultivars.

For additional information, see Anet 1974a, 1974b; Bain and Mercer 1963; Bramlage and Meir 1989; Chen et al. 1985; Feys et al. 1980; Gough and Shutak 1972; Hanekom et al. 1976; Hardenburg and Anderson 1981; Huelin and Coggolia 1968, 1970a, 1970b; Ingle and D'Souza 1989; Klein and Lurie 1992; Lau 1990; Little et al. 1985; Lurie et al. 1989; Watkins et al. 1988.

\section{Soft scald}

Soft scald, also called ribbon scald or deep scald, is a low-temperature disorder of apples. It is induced in susceptible cultivars by storing them at temperatures of $2.2^{\circ} \mathrm{C}$ or lower. In low-temperature storage, 
the disorder is most likely to be found in fruit exposed to cold air discharged from the evaporator coils. Soft scald is not related to common scald and its causes and control are quite different. In its various stages, soft scald affects the skin only, but it may damage hypodermal tissue as the lesion continues to develop. Skin lesions are often invaded by secondary infections of Cladosporium or Alternaria, which cause diffuse black spots.

Soft scald may develop rapidly in storage between mid November and late December, but unlike common scald and various senescent disorders, development stops when the fruit is removed from cold storage. Soft scald is easily identified by the sharply defined, irregularly shaped, smooth brown areas in the skin of the apple (Figs. 38 and 39). One or more small lesions may occur, or the disorder may affect most of the apple, irrespective of skin color, but seldom at the stem or calyx end.

Fruit with soft scald has a low content of linoleic acid; dips in fatty acids, edible oils, and antioxidants markedly reduce or prevent the disorder. Soft scald can be induced chemically by injections of hexanol or hexyl acetate into the core cavity. The disorder is likely to occur when highly respiring susceptible cultivars are cooled rapidly. Delayed cooling can advance the onset of the climacteric and thus render the fruit more prone to soft scald upon subsequent rapid cooling. The disorder is prevented if the apples are subjected to $20-30 \% \mathrm{CO}_{2}$ for 2 days during the cooling period. Heating the fruit to $38-42^{\circ} \mathrm{C}$ for $8-12$ hours before placing it in cold storage also produces a marked reduction in soft scald. Although susceptibility to soft scald varies with the season, the disorder can be controlled by harvesting the fruit at the correct maturity and placing it in cold storage promptly. When these handling requirements cannot be met or when they are inadequate for certain cultivars, the fruit should be stored at temperatures not lower than $2.5^{\circ} \mathrm{C}$ for the first $6-8$ weeks.

For additional information, see Eaves and Hill 1940; Fisher 1942; Hopkirk and Wills 1981; McColloch et al. 1965; Padfield 1969; Pierson et al. 1971; Wills and Hopkirk 1981; Wills et al. 1980.

\section{Water core}

Water core is a preharvest disorder of apples that is characterized by the presence of liquid-soaked tissue around the vascular bundles (Fig. 40). In advanced cases, the core cavity and most of the tissue surrounding the vascular bundles contain liquid (Fig. 41). The soaked or glassy appearance results from liquid accumulation in the intercellular space.

Although water core is a widely accepted term for the disorder, it is imprecise, because affected tissue may be found outside the core area. In severe cases, most of the tissue is damaged, even to the extent that the lenticels secrete droplets of sap. The liquid in affected tissue has a soluble-solids content comparable to juice from normal tissue. The main carbohydrates in apple juice are sucrose, glucose, and fructose, but in water core tissue the intercellular spaces are filled 
with a sorbitol solution, an important carbohydrate in apple tree sap. Sorbitol is not used directly by apple tissue but must first be converted to fructose. Water core tissue lacks the ability to convert sorbitol to fructose. Severe water core results in an accumulation of ethanol and acetaldehyde. In high quantities, both are toxic to apple tissue and cause flesh browning and breakdown during storage.

Fruit with small areas of water core tissue often recovers completely during several months in cold storage. Flesh browning and breakdown, however, are likely to develop in severely affected fruit. Keeping fruit at warm temperatures after harvest hastens the disappearance of water core, but it also accelerates ripening and the possibility of breakdown.

Microscopy has revealed significant differences in vascular tissue between cultivars susceptible and resistant to water core. Water core can be detected by the transmission of light, but a nuclear magnetic resonance technique can better define and locate the disorder. Water core is promoted by large fruit size, a high leaf-to-fruit ratio, excessive thinning, heavy pruning, high light exposure, and girdling of limbs or trunk. Maturity, however, is the most influential factor; changes in membrane leakage or altered transport are viewed as probable causes of the disorder. The disorder becomes evident when the fruit begins to ripen. Ethrel sprays, which advance maturity, can induce extensive water core if the fruit is not harvested at the appropriate time. This may occur even in cultivars that rarely develop the disorder, such as McIntosh. Conversely, delaying maturity may reduce water core. Low night temperatures in the fall may hasten maturation and thus promote the development of water core. Low growing-temperatures markedly increase sorbitol concentration in the tracheal sap of apple trees.

Another type of water core that is unrelated to maturity may occur in mid season during or after a period of unusually hot weather. In this type, small areas of affected tissue may be found throughout the flesh, or as extensive patches of liquid-soaked tissue, often visible through the skin, on the exposed side of the apple. In Newtown, for example, this is sometimes associated with sunscald.

The development of water core does not appear to be influenced by the availability of water. Experiments have shown, however, that water core is reduced by raising the calcium content of the fruit and is increased by high applications of nitrogen and boron. The best way to minimize water core in apples is to avoid late harvesting. Susceptible cultivars include Bramley's Seedling, Cox's Orange Pippin, Delicious, James Grieve, Jonathan, Miller Seedling, Stayman, Wagener, and Winesap. Less susceptible cultivars are Cortland, Golden Delicious, Granny Smith, McIntosh, and Newtown.

For additional information, see Faust et al. 1969; Knee et al. 1983; Kollas 1968; Marlow and Loescher 1985; Nardin and Scienza 1983; Simons 1968; Smagula et al. 1968; Wang et al. 1988. 

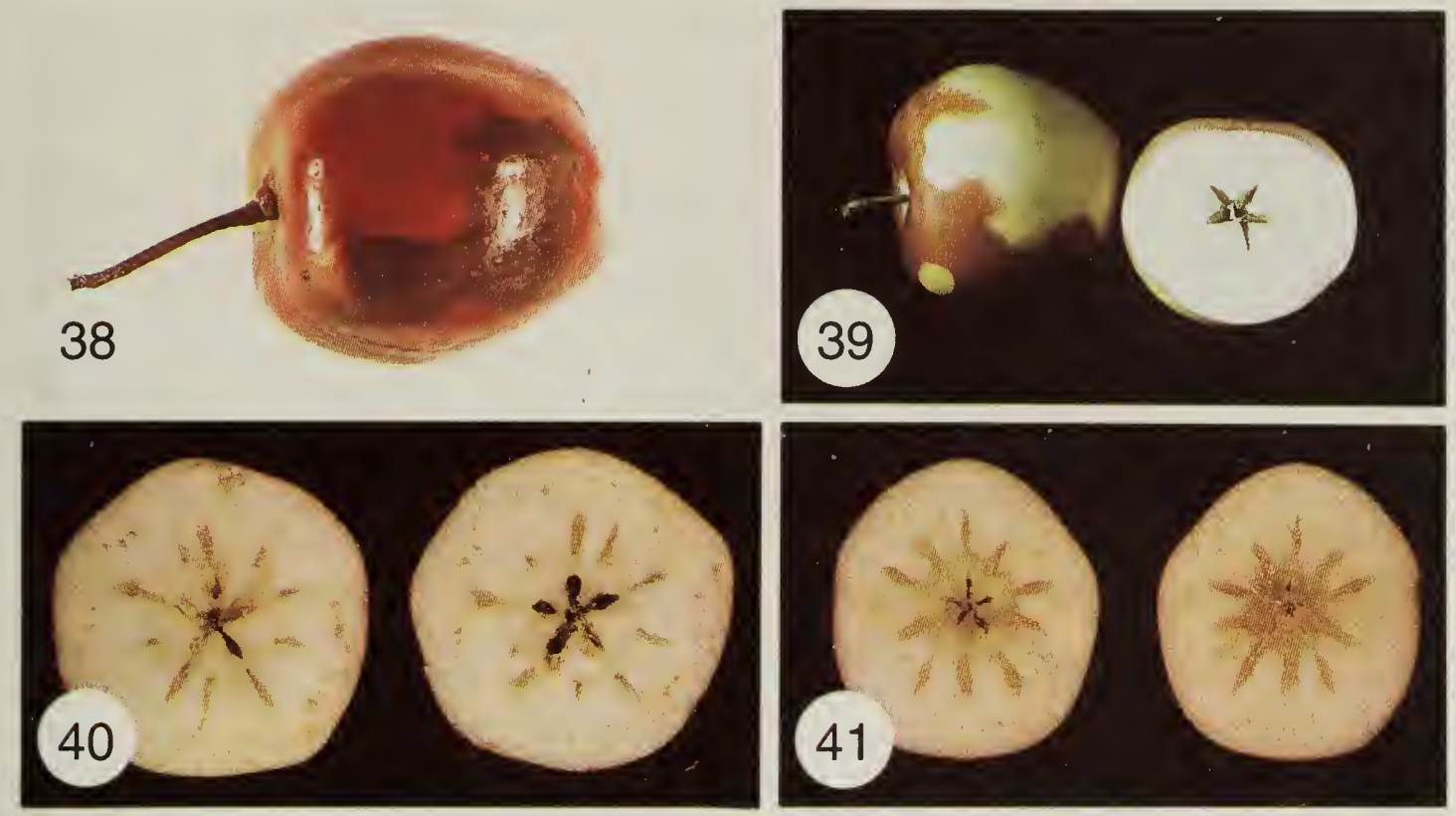

Fig. 38 Soft scald (Delicious)

Fig. 39 Soft scald (Golden Delicious)

Fig. 40 Vascular water core (Delicious)

Fig. 41 Core and vascular water core (Delicious) 


\section{Physiological disorders of pears}

\section{Alfalfa greening}

The disorder, also known as green stain, is confined to Anjou pears grown in the Pacific Northwest and is characterized by dark green specks, blotches, or longitudinal streaks on the skin (Fig. 42), particularly around the stem area. Even though dessert quality is not altered, the fruit is culled commercially. Skin staining begins 3-6 weeks before harvest. Fruit with the disorder has higher levels of $N$, $\mathrm{P}$, and $\mathrm{K}$ and lower levels of $\mathrm{Ca}$ than does sound fruit. High $\mathrm{N}: \mathrm{Ca}$ ratios and frequent irrigation are conducive to the disorder. Calcium sprays are beneficial, but high concentrations can cause appreciable skin injury. Slow drying conditions or high temperatures during spraying render the fruit and leaves more sensitive to spray injury. Superficial cork often accompanies alfalfa greening, as both are associated with a low calcium content in the fruit.

For more information, see Raese and Stahly 1982; Kaese and Staiff 1983; Raese 1989; Raese et al. 1979, 1982.

\section{Bitter pit (cork spot, Anjou pit)}

Bitter pit (also known as cork spot and Anjou pit) in pears is an abnormality in the cortical tissue. It develops during the latter part of the growing season and is quite similar to bitter pit in apples. Patches of corky brown tissue, usually near the calyx end, occur deep in the tissue or immediately under the skin and appear externally as dark green sunken areas (Fig. 43). Affected fruit becomes partly yellow and softens prematurely, even in storage. Anjou and Packham's Triumph pears are highly susceptible to cork spot. Cultural practices that minimize bitter pit in apples are also effective for cork in pears.

Tissue prone to cork is low in calcium or has a high $\mathrm{K}: \mathrm{Ca}$ ratio, respires more intensely, produces more ethylene and has a higher chlorogenic acid content in the skin. High rates of nitrogen application increase the incidence of the disorder. Calcium sprays have a beneficial effect on the prevention of cork spot; late sprays are more effective than early sprays and multiple sprays are more effective than single sprays. Efficacy depends on concentration, but risk of phytotoxicity also increases.

For additional information, see Raese 1989; Raese and Stahly 1982; Raese and Staiff 1989; Richardson and Al-Ani 1982; Richardson and Lombard 1979; Snowdon 1990; Wang and Mellenthin 1973.

\section{Black end}

The disorder, restricted to pears, is often characterized by a black discoloration of the calyx end (Fig. 44). The calyx end may become peaked or flattened; the epidermal tissue is tight and glossy. Studies suggest that the disorder is initiated 45-60 days after full bloom. Black spots may extend to the stem end in severe cases, and cracks to 
the core area in the calyx area may be present. Hard end is another manifestation of black end, but no discoloration occurs in the calyx area. Affected tissue remains hard, very gritty, and seldom softens upon ripening. Fruit with the disorder is smaller and grows more slowly; tissue in the calyx area is lower in $\mathrm{Ca}$ and $\mathrm{B}$, higher in polyphenoloxidase activity, and higher in soluble solids content. Fruit grown on Pyrus serotina rootstock is more prone to the disorder than on other rootstocks. No leaf symptoms are evident in trees with black end fruit, but such trees have a tendency to bear black end fruit each year. Cultivars susceptible to the disorder are Anjou, Bartlett, Winter Nelis, Flemish Beauty, Comice, Easter, and Clairgeau; susceptibility may differ with growing area.

For additional information, see Raese 1989; Taylor et al. 1987; Woodbridge 1971; Yamamoto and Watanabe 1982.

\section{Carbon dioxide injury}

Pears are considerably less tolerant of $\mathrm{CO}_{2}$ than are apples. Injury is first evident as browning of the interior carpel walls. As the disorder progresses, the core tissue adjacent to the carpels turns brown (Figs. 45 and 46). More extensive injury of cortical tissue turns the tissue light brown in unripened fruit. As desiccation proceeds, cavities develop that may be either small and scattered or large enough for a depression on the surface to occur. Skin and subepidermal tissue are rarely affected.

Brown core in Anjou pears consists of brown core tissue interspersed with cavities. Pithy brown core in Bosc is similar to Anjou brown core, but core and cortical tissue may contain cavities. $\mathrm{CO}_{2}$ injury in Bartlett pears affects core tissue next to the vascular region but outside the core line. Anjou pears stored in controlled-atmospheres have recently suffered a disorder that produces small brown necrotic lesions on the skin. This disorder is associated with advanced maturity. The susceptibility of pears to $\mathrm{CO}_{2}$ injury increases with advanced fruit maturity, delayed storage, slow cooling, high storage temperatures, prolonged storage, and low oxygen levels in the atmosphere.

Fruit from trees of low vigor and fruit grown in cool seasons are quite sensitive to $\mathrm{CO}_{2}$. Injury for a given $\mathrm{CO}_{2}$ level is negatively correlated to the oxygen content of the atmosphere.

For additional information, see Blanpied 1975a; Chen et al. 1986; Claypool 1973; Couey and Wright 1977; Hansen 1957, 1963; Hansen and Mellenthin 1962; Kerbel et al. 1988; Lee et al. 1990; Raese 1989.

\section{Chemical injury}

During handling and storage, pears may be exposed to some chemicals that could be injurious through misuse or because of fruit sensitivity. Current postharvest practices for pears include the use of scaldinhibiting chemicals, fungicides, calcium salts to control breakdown 
and bitter pit, salts to increase fruit buoyancy in flotation systems, detergents to clean fruit, and waxes to enhance appearance.

\section{Ammonia}

Comments regarding ammonia injury in apples are applicable to pears. Bartlett and Anjou pears exposed to ammonia develop brown or tan halos around the lenticels (Fig. 47). The color changes are not readily reversible.

For more information, see Dewey 1952; Pierson et al. 1971; Ramsey and Butler 1928.

\section{Calcium salts}

Anjou pears sprayed with $\mathrm{CaCl}_{2}$ to control cork spot in the fruit can develop surface marking because of sensitivity to the salt. The incidence of marking is reduced significantly when lower concentrations of the salt are combined with a surfactant. Dips in $\mathrm{CaCl}_{2}$ solutions to retain fruit quality in Bartlett pears have resulted in external black necrotic spots and skin discoloration similar to scald.

For more information, see Meheriuk 1990; Raese 1989.

\section{Ethoxyquin}

Injury in the form of pinkish or black lesions has been reported for Anjou pears treated with ethoxyquin (Fig. 48). In Oregon, concentrations of $1350 \mathrm{ppm}$ or more were, on occasion, phytotoxic to Anjou pears. It is believed that injury can be attributed to solution concentration at points of contact after dipping.

For more information, see Chen et al. 1990.

\section{Flotation salts}

Salts are added to the flotation water to make pears buoyant. A specific gravity of 1.2 is needed to float pears, in contrast to apples, which float in water because their specific gravity is less than that of water. Sodium carbonate and sodium silicate produce an alkaline solution. If fruit remains in the solution for extended periods or is not rinsed after flotation, lenticel injury, as black spots (Fig. 49), may occur, becoming evident during subsequent storage. Sodium sulfate does not have any phytotoxic effects but may be more difficult to dissolve.

For more information, see Visagie and Redelinghuys 1975.

\section{Freezing Injury}

For a discussion on the physiology of freezing, consult the same topic under apples. Long exposure to mild freezing temperatures results in 

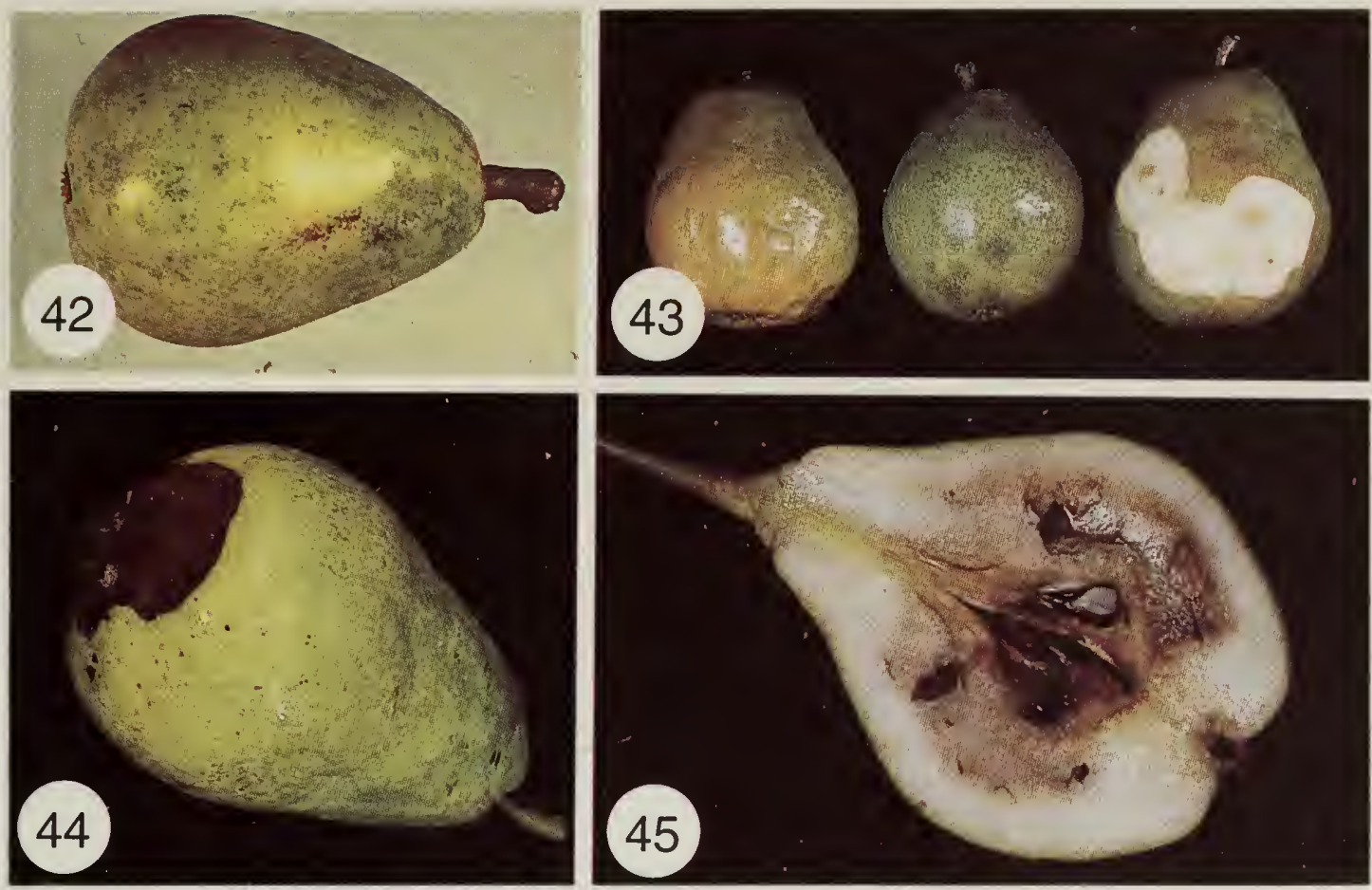

Fig. 42 Alfalfa greening (Anjou)

Fig. 43 Bitter pit (Anjou)

Fig. 44 Black end (Bartlett)

Fig. 45 Carbon dioxide injury (Clapp's Favorite) 
a layer of healthy tissue immediately below the skin, followed by a layer of water-soaked tissue (Fig. 50). The cortical tissue in such fruit shows brown vascular bundles, with brown cortical tissue in more severe cases. Severe freezing causes cavitation in the cortex (Fig. 51).

Freezing points in pears depend on the quantity of dissolved sugars and electrolytes in the cytoplasm; the freezing point among Bartlett pears can differ by as much as $1^{\circ} \mathrm{C}$. A soluble-solids content of less than $8 \%$ in Bartlett pears has resulted in a freezing point of $-1.2^{\circ} \mathrm{C}$. Most pears, however, have a freezing point of $-2^{\circ} \mathrm{C}$ or lower.

For more information, see Fisher et al. 1953.

\section{Core breakdown}

Core breakdown is a senescent disorder in which core tissue becomes brown, watery (Fig. 52) and, in the case of Bartlett, is easily separated from the healthy tissue. Main vascular elements also turn dark brown. Breakdown in Bosc pears that have been stored for long periods may be preceded by vascular browning as the fruits ripen at room temperature.

Factors that influence core breakdown are crop load, harvest date, storage temperature, delayed cooling, and delayed storage. Treatments that reduce core breakdown in Bartlett pears are calcium dips, high $\mathrm{CO}_{2}$, and heat. A causal relationship has been suggested for acetaldehyde accumulation and core breakdown in Bartlett pears.

The time between ripening and the occurrence of breakdown is important to the processor and the consumer. This interval, which may be a week or more in fruit ripened soon after harvest, decreases with late harvesting, adverse storage conditions, or extended storage. When cultivars such as Bartlett and Bosc, which ordinarily do not ripen at low temperatures, are kept too long in cold storage and then transferred to room temperature $\left(20^{\circ} \mathrm{C}\right)$ for several days, core breakdown may occur before the fruit has fully ripened. Yellowing of pears during storage is often a good indication of high susceptibility to core breakdown. Further storage often leads to the development of senescent scald and a complete inability to ripen. Other cultivars, such as Anjou, Packham's Triumph, and Winter Nelis, which are capable of ripening slowly at low temperature, may develop core breakdown while in cold storage.

Controlled-atmosphere storage extends the storage life of pears and thus reduces the development of core breakdown. Some late-picked Bartlett pears in California developed a watery breakdown when stored at higher temperatures or were delayed in cooling.

For additional information, see Blanpied 1975b; Hall and Scott 1972; Harley 1929; Meheriuk 1990; Mitchell and Mayer 1973; Porritt 1965; Raese 1989. 


\section{Friction marking}

Most plant cells undergo enzymatic browning when injury exposes the cell contents to oxygen. Browning of injured vegetative tissue and of fruit results from a reaction of polyphenoloxidase with naturally occurring phenols such as chlorogenic acid and catechol in the presence of oxygen (Fig. 53). The brown-colored products of these reactions are orthoquinones, which polymerize to form more intensely colored substances. Fruits that contain the enzyme and phenolics for browning are apples, pears, apricots, peaches, and cherries; but citrus fruit, pineapples, and tomatoes are deficient in the enzyme and do not brown. Skin abrasions caused by handling, packing, or transit may result in browning of the skin and the underlying tissue of pears, apples, apricots, and peaches. Pears are very susceptible, often sustaining friction marking by the movement of one fruit against an other or against the sides of bulk bins. Such abrasion can take place in the orchard, during packing, or in transit. The extent of friction marking in pears is related to the chlorogenic acid content in the skin.

The concentration of phenolics in the skin of Anjou pears declines with advancing fruit maturity but increases again during storage. This finding is consistent with the observation that small pears picked early scuff more readily than mature fruit and that later packing of pears is likely to result in a higher incidence of friction marking than earlier packing.

Antioxidants such as ascorbic acid and sulfur dioxide, and the enzyme inhibitor 2-mercaptobenzothiazole, reduce or prevent browning of pear skin. High $\mathrm{CO}_{2}$ treatments and surface-coating materials also reduce the incidence of friction marking in pears. At present, however, no chemicals are permitted for the control of friction marking of pears. The most effective way to minimize friction marking of pears is to modify handling and packing procedures. For example, use greater care in moving fruit containers in the orchard; use bulk bins with rigid bottoms; if necessary, line the sides of bins with a smooth material; reduce the speed of brushes when the fruit is being cleaned or dispense with brushes on the packing line; and make sure that the fruit packs are tight enough to prevent movement of fruit during transit.

Less friction marking occurs on pears that are picked at the correct maturity and are packed within 3 to 4 weeks of harvest. If they are packed directly from cold storage, do not warm them before packing. Such a procedure is likely to increase scuffing and to reduce storage life. Avoid unnecessary drying of pears, because water lubricates the fruit on the packing line. Because polyphenoloxidase is less active under acidic conditions, it is advisable to avoid the use of alkaline salts in flotation systems for pears.

For additional information, see Couey and Wright 1977; Kvale 1979, 1988; Mellenthin et al. 1982; Mellenthin and Wang 1974; Raese 1989; Smith 1946; Sommer et al. 1960. 

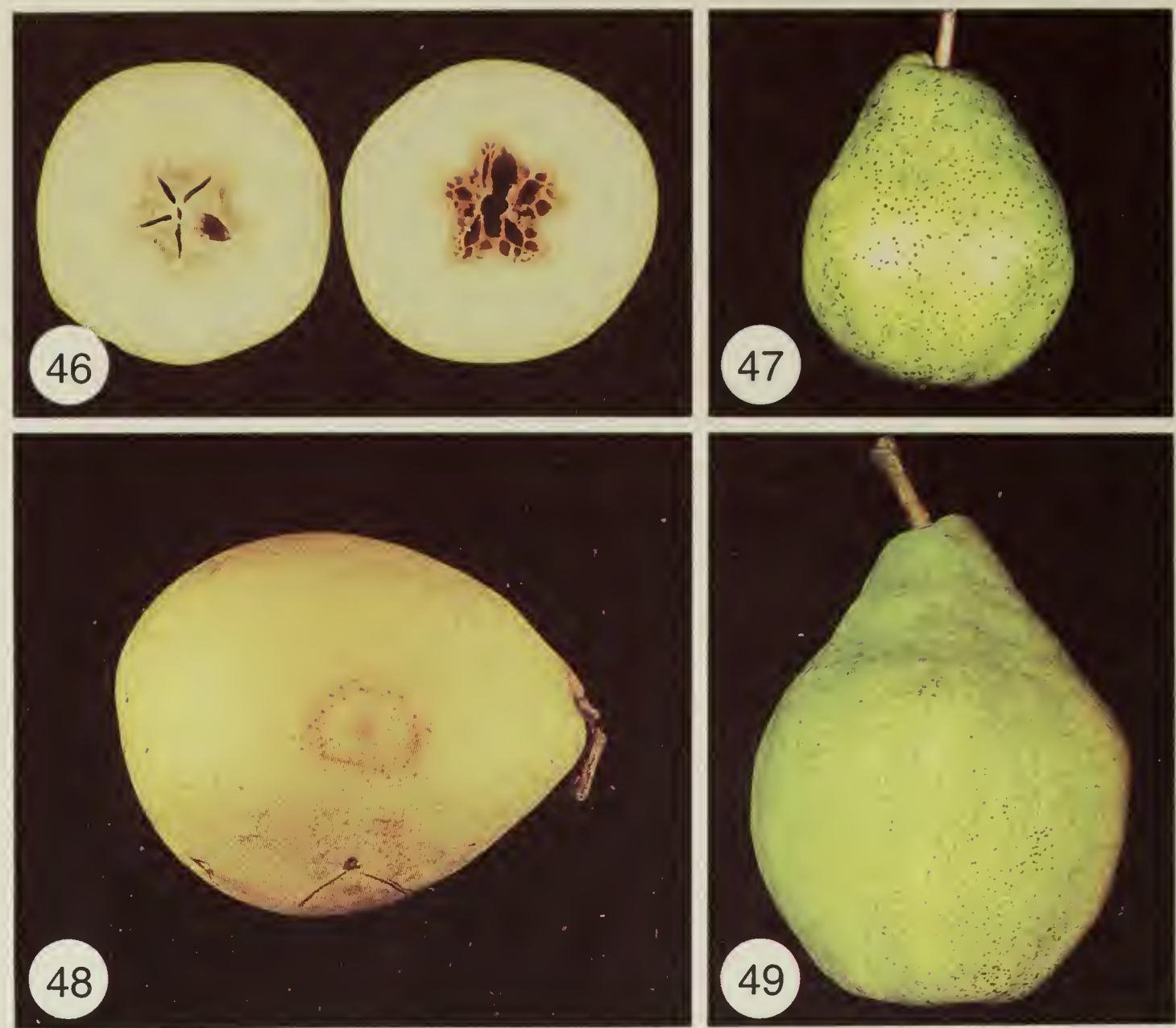

Fig. 46 Carbon dioxide injury (Anjou)

Fig. 47 Ammonia injury (Anjou)

Fig. 48 Ethoxyquin injury (Anjou)

Fig. 49 Sodium carbonate injury (Bartlett) 

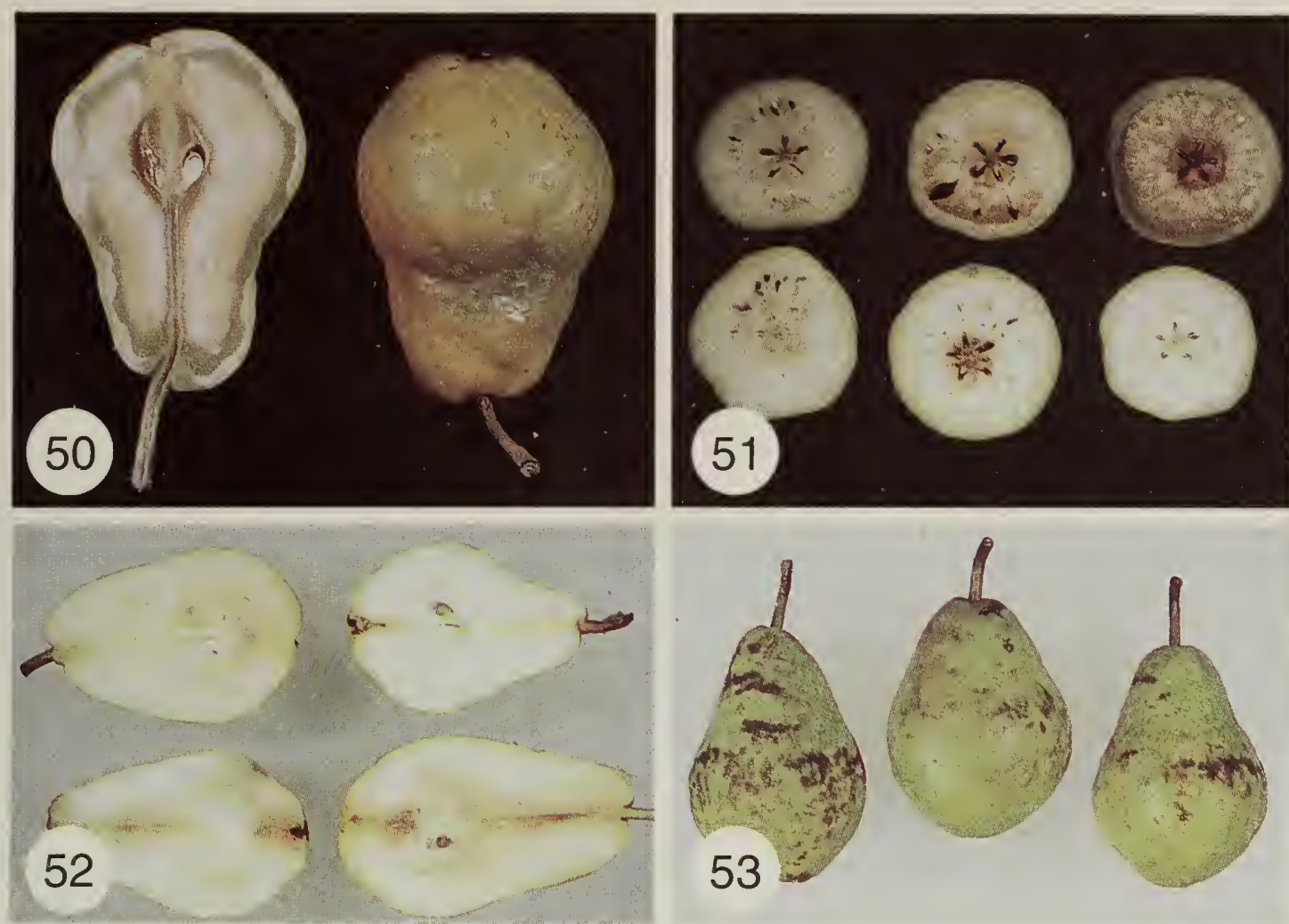

Fig. 50 Freezing injury (Bartlett)

Fig. 51 Acute freezing injury (Bartlett)

Fig. 52 Core breakdown (Bartlett)

Fig. 53 Friction marking (Bartlett) 


\section{Low-oxygen injury}

Low-oxygen injury of pears has been reported only once. Lateharvested Bosc pears in Oregon developed core browning during storage in $1 \% \mathrm{O}_{2}$. Fruit picked at the correct maturity did not show any signs of core browning under the same storage conditions. It was therefore suggested that the late-harvested fruit had suffered a form of low-oxygen injury.

For more information, see Chen et al. 1983.

\section{Pink end}

When cold weather occurs in the latter part of the growing season, Bartlett pears sometimes begin ripening on the tree before the usual harvest time. The disorder is routinely called pink end but is also known as premature ripening. Early yellowing of fruit at the calyx basin, accelerated softening, and pink coloring of the fleshy calyx (pink end) indicate premature ripening (Figs. 54 and 55). Serious losses can occur unless the fruit is harvested at the first signs of ripening, cooled quickly, and sold promptly. Depending on the severity of the disorder, harvested fruit may continue to ripen and undergo complete breakdown if the fruit is placed in warm temperatures after cold storage.

Breakdown associated with premature ripening is somewhat different from core or senescent breakdown. It occurs at the calyx basin, where the soft light brown color of affected tissue is clearly visible through the skin of the fruit, in contrast to core breakdown, which is not visible externally.

Pink end can be initiated when night temperatures of about $7^{\circ} \mathrm{C}$ or lower occur during the last 4 weeks of fruit growth. When day temperatures are $20^{\circ} \mathrm{C}$ or lower, the accumulation of about $25 \mathrm{~h}$ of night temperatures of $7^{\circ} \mathrm{C}$ or lower is sufficient to stimulate ethylene production and the onset of fruit ripening. When day temperatures are higher than $20^{\circ} \mathrm{C}$, a longer exposure to chilling is required to initiate ripening, or premature ripening may be averted entirely. Gibberellic acid applied about 4 weeks before harvest counteracts the effect of low temperature.

For additional information, see Mellenthin and Wang 1977; Raese 1989; Wang and Mellenthin 1972; Wang et al. 1971.

\section{Russet}

This disorder is associated with apples; russet that appears on pears is a genetic trait. Bosc and Russet Bartlett, for example, are completely russeted at harvest. 


\section{Scald}

Pears can be classified broadly into two groups based on ripening characteristics. One group of pears, including Anjou, Winter Nelis, Packham's Triumph, and Hardy, do not lose their capacity for normal ripening as a result of extended storage. Anjou pears are susceptible to storage scald (Fig. 56) and, like apples, they respond to control measures with oil wraps, ethoxyquin, or diphenylamine. Low oxygen and high $\mathrm{CO}_{2}$ treatments before storage are also effective scald control measures for Anjou pear.

The other group of pears, which includes Bartlett, Bosc, Howell, Comice, Sierra, and Flemish Beauty, lose their ability to ripen when stored for extended periods. The fruit turns yellow and eventually develops a dark brown discoloration of the skin called senescent scald (Fig. 57). This may occur in cold storage or when the fruit is removed from cold storage and subjected to warm ripening. The fruit is inedible and remains firm, but the skin does slough off easily. Reducing the storage period is the only control measure available.

For additional information, see Couey and Wright 1977; Eksteen et al. 1986; Hansen and Mellenthin 1967; Mellenthin et al. 1980; Padfield 1969; Pierson et al. 1971; Pierson and Schomer 1967; Raese 1989. 


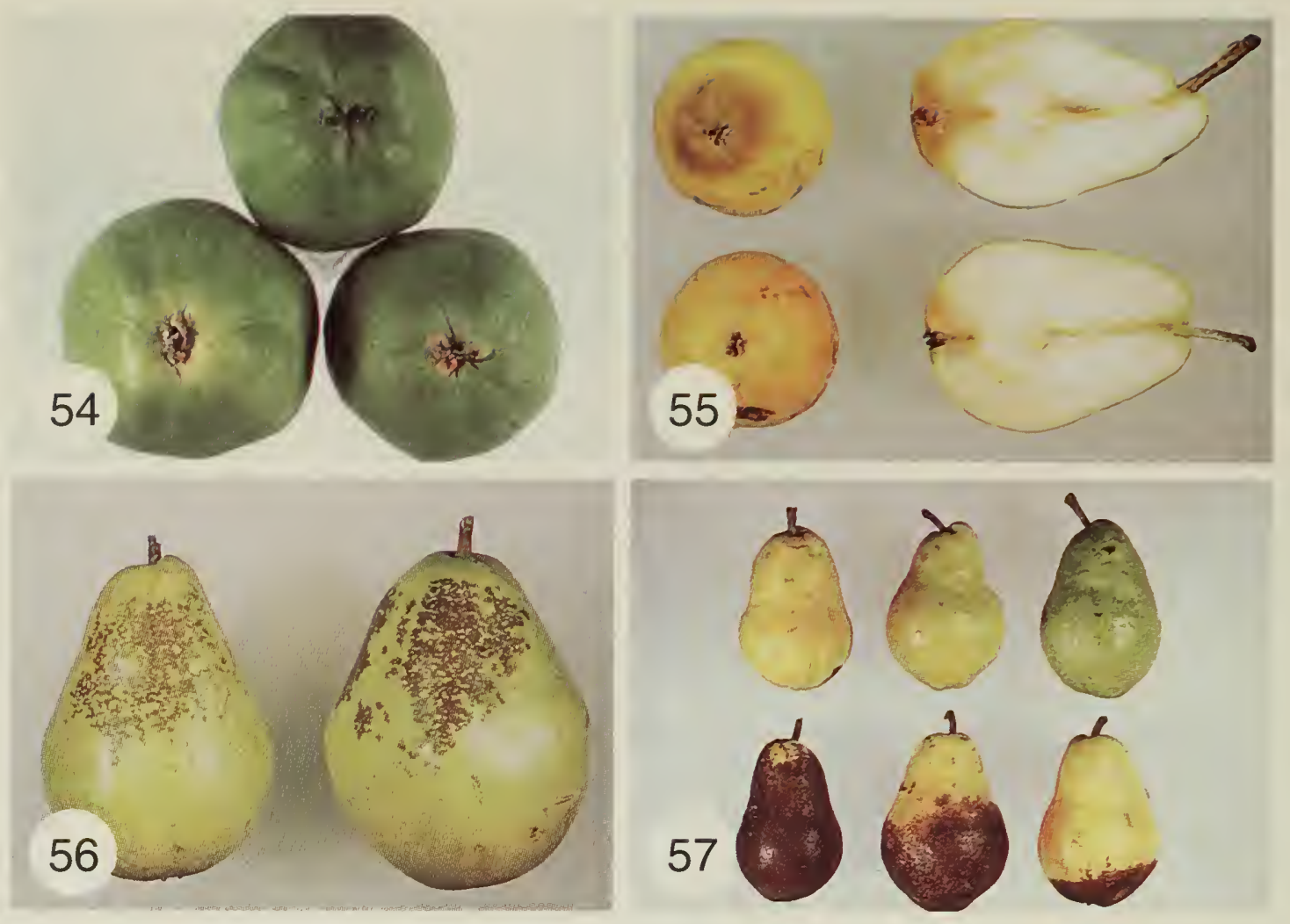

Fig. 54 Pink end, early symptoms (Bartlett)

Fig. 55 Pink end, advanced symptoms (Bartlett)

Fig. 56 Superficial scald (Anjou)

Fig. 57 Senescent scald (Bartlett) 


\section{References cited}

Anet, E.F.L.J. 1974a. Superficial scald. CSIRO Food Res. Quart. 34:4-8.

Anet, E.F.L.J. 1974b. Superficial scald, a functional disorder of stored apples. XI. Apple anti-oxidants. J. Sci. Food Agric. 25:299-304.

Ashizawa, M.; Horigome, Y.; Chujo, T. 1984. Histological studies on the cause of russet in Golden Delicious apple. Tech. Bull. Agric. Kagawa Univ. 35:88-98.

Askew, H.O.; Chittendon, E.T.; Monk, R.J.; Watson, J. 1959. Chemical investigations on bitter pit of apples. I. Physical and chemical changes in leaves and fruits of Cox's Orange variety during the season. N.Z. J. Agric. Res. 2:1167-1186.

Askew, H.O.; Chittendon, E.T.; Monk, R.J.; Watson, J. 1960a. Chemical investigations on bitter pit of apples. II. The effect of supplementary mineral sprays on incidence of pitting and on chemical composition of Cox's Orange fruit and leaves. N.Z. J. Agric. Res. 3:141-168.

Askew, H.O.; Chittendon, E.T.; Monk, R.J.; Watson, J. 1960b. Chemical investigations on bitter pit of apples. III. Chemical composition of affected and neighbouring healthy tissues. N.Z. J. Agric. Res. $3: 169-178$.

Autio, W.R.; Bramlage, W.J.; Weis, S.A. 1986. Predicting poststorage disorders of 'Cox's Orange Pippin' and 'Bramley's Seedling' apples by regression equations. J. Am. Soc. Hortic. Sci. 111:738-742.

Bain, J.M.; Mercer, F.V. 1963. The submicroscopic cytology of superficial scald, a physiological disease of apples. Aust. J. Biol. Sci. 16:442-449.

Balzacs, E.; Toth, A. 1974. Jonathan spot induced by ultraviolet light. Acta Phytopathol. Acad. Sci. Hung. 9:179-184.

Bangerth, F. 1970. Bitter pit of apples, a still-unsolved problem of fruit physiology. Gartenbauwissenschaft 35:91-120.

Bangerth, F. 1973. Investigations upon $\mathrm{Ca}$ related physiological disorders. Phytopathol. Z. 77:20-37.

Bangerth, F. 1974. Problems of plant physiology in relation to bitter pit. The function of calcium. Acta Hortic. 45:43-52.

Bergh, O.; Franken, J.; Van Zyl, E.J.; Kloppers, F.; Dempers, A. 1980. Sunburn on apples - preliminary results of an investigation conducted during the 1978/79 season. Decid. Fruit Grower 30:8-22.

Bir, R.E.; Bramlage, W.J. 1973. Postharvest effects of freezing on apples. J. Am. Soc. Hortic. Sci. 98:218-221.

Bir, R.E.; Bramlage, W.J.; Havis, J.R. 1973. Effects of freezing on mature apple fruit tissue. J. Am. Soc. Hortic. Sci. 98:215-218. 
Blanpied, G.D. 1975a. Pithy brown core occurrence in 'Bosc' pears. J. Am. Soc. Hortic. Sci. 100:81-84.

Blanpied, G.D. 1975b. Core breakdown of New York 'Bartlett' pears. J. Am. Soc. Hortic. Sci. 100:198-200.

Blanpied, G.D. 1981. A relationship between water loss and storage breakdown of 'McIntosh' apples. HortScience 16:525-526.

Bramlage, W.J.; Bareford, P.H.; Blanpied, G.D.; Dewey, D.H.; Taylor, S.; Porritt, S.W.; Lougheed, E.C.; Smith, W.H.; McNicholas, F.S. 1977. Carbon dioxide treatments for 'McIntosh' apples before CA storage. J. Am. Soc. Hortic. Sci. 102:658-662.

Bramlage, W.J.; Drake, M.; Weiss, S.A. 1985. Comparisons of calcium chloride, calcium phosphate, and a calcium chelate as foliar sprays for 'McIntosh' apple trees. J. Am. Soc. Hortic. Sci. 110:786-789.

Bramlage, W.J.; Meir, S. 1989. A potential method for predicting susceptibility of apples to superficial scald. Acta Hortic. 258:397-403.

Brennan, E.; Leone, I.; Daines, R.H. 1962. Ammonia injury to apples and peaches in storage. Plant Dis. Rep. 46:792-795.

Brooks, C.; Fisher, D.F. 1926. Some high-temperature effects in apples: contrasts in the two sides of an apple. J. Agric. Res. 32:1-16.

Bünemann, G. 1972. Annotated bibliography on bitter pit of apples. Techn. Univ. Berlin Biblio. Series 2. 170 pp.

Burmeister, D.M.; Dilley, D.R. 1991. Induction of bitter pit-like symptoms on apples by infiltration with $\mathrm{Mg}^{+2}$ is attenuated by $\mathrm{Ca}^{+2}$. Postharvest Biol. Technol. 1:11-17.

Cappelini, P. 1970. Russeting in Golden Delicious fruits from healthy and russeted clones. Ann. Ist. Sper. Fruttic. 1:49-61.

Carne, W.M. 1948. The non-parasitic disorders of apple fruits in Australia. CSIR Bull. No. 238. 83 pp.

Carne, W.M.; Martin, D. 1938. The influence of carbon dioxide concentration on brown heart and other storage disorders. CSIRO J. (Aust.) 11:47-60.

Carrick, D.B. 1924. Some aspects of freezing on mature fruits of the apple. N.Y. Agric. Exp. Sta. Mem. 81.54 pp.

Carrick, D.B. 1928. The effect of freezing on the respiration of the apple. N.Y. Agric. Exp. Sta. Mem. 110. 28 pp.

Carroll, E.T. 1968. Core flush in apples. Proceedings 5th Australian Fruit and Vegetable Storage Research Confrence, August 1968, Hobart, Australia.

Chamel, A.R.; Bossy, J.P. 1981. Electron-microprobe analysis of apple fruit tissues affected with bitter pit. Scientia Hortic. 15:155-163. 
Chen, P.M.; Borgic, D.M.; Sugar, D.; Mellenthin, W.M. 1986. Influence of fruit maturity and growing district on brown-core disorder in 'Bosc' pears. HortScience 21:1172-1173.

Chen, P.M.; Mellenthin, W.M.; Kelly, S.B. 1983. Fruit quality of 'Bosc' pears (Pyrus communis L.) stored in air or one percent oxygen as influenced by maturity. Scientia Hortic. 21:45-52.

Chen, P.M.; Olsen, K.L.; Meheriuk, M. 1985. Effect of low-oxygen atmosphere on storage scald and quality preservation of 'Delicious' apples. J. Am. Soc. Hortic. Sci. 110:16-20.

Chen, P.M.; Varga, D.M.; Mielke, E.A.; Facteau, T.J.; Drake, S.R. 1990. Control of superficial scald on 'd'Anjou' pears by ethoxyquin: effect of ethoxyquin concentration, time and method of application, and a combined effect with controlled atmosphere storage. J. Food Sci. 55:167-170.

Chiu, H.J. 1984. Effects of pre-storage and storage treatments on brown core development in 'McIntosh' apples. Acta Hortic. $157: 135-142$.

Claypool, L.L. 1973. Further studies on controlled atmosphere storage of 'Bartlett' pears. J. Am. Soc. Hortic. Sci. 98:289-293.

Clijsters, H. 1965. Malic acid metabolism and initiation of the internal breakdown in Jonathan apples. Physiol. Plant. 18:85-94.

Coccuci, M.; Lamiani Mignani, I.; Coccuci, S.; Poma Treccani, C. 1983. A possible relationship between bitter pit and membrane transport in apples. Acta Hortic. 138:43-50.

Couey, H.M.; Wright, T.R. 1977. Effect of a prestorage $\mathrm{CO}_{2}$ treatment on the quality of 'd'Anjou' pears after regular or controlled atmosphere storage. HortScience 12:244-245.

Dalton, R.; Nel, P.J.; November, A.; Eksteen, G.J. 1982. Post-harvest procedure for reducing core flush in Granny Smith apples. Decid. Fruit Grower 32:194-201.

Dewey, D.H. 1952. Ammonia damage to stored fruits and nuts, sulfur dioxide as a corrective treatment. Ice Refrig. 123:19-22.

Eaves, C.A.; Hill, H. 1940. Functional disorders of apples. Agric. Can. Tech. Bull. 28. 19 pp.

Eccher, T. 1986. Russet and shape of Golden Delicious as related to endogenous GA content of fruitlets. Acta Hortic. 179:767-770.

Eksteen, G.J. 1980. Recommendations for the application of DPA. Decid. Fruit Grower 30:82-88.

Eksteen, G.J.; Ginsburg, L.; Visagie, T.R. 1977. Post-harvest prediction of bitter pit. Decid. Fruit Grower 27:16-20.

Eksteen, G.J.; van Rhyn, J.A.G.; de Villiers, J.F. 1986. The effects of post-harvest calcium treatments on the uptake of calcium and quality of Bon Chretien pears. Decid. Fruit Grower 36:54-58. 
Faust, M.; Shear, C.B. 1968a. Corking disorders of apples: a physiological and biochemical review. Bot. Rev. 34:441-469.

Faust, M.; Shear, C.B. 1968b. Investigation of corking disorders of apples. III. Biochemical changes during the development of cork spot of 'York Imperial' apples. Proc. Am. Soc. Hortic. Sci. 93:746-752.

Faust, M.; Shear, C.B. 1972. Russeting of apples, an interpretive review. HortScience 7:233-235.

Faust, M.; Shear, C.B.; Williams, M.W. 1969. Disorders of carbohydrate metabolism of apples. Bot. Rev. 35:168-194.

Ferguson, I.B.; Watkins, C.B. 1983. Cation distribution and balance in apple fruit in relation to calcium treatments for bitter pit. Scientia Hortic. 19:301-310.

Feys, M.; Naesens, W.; Tobback, P.; Maes, E. 1980. Lipoxygenase activity in apples in relation to storage and physiological disorders. Phytochemistry 19:1009-1011.

Fidler, J.C.; North, C.J. 1965. Core flush in apples. Proceedings International Congress on Storage Distribution of Vegetables and Fruit, Bologna, Italy, 28-30 May 1963, Vol I.

Fidler, J.C.; North, C.J. 1970. Sorbitol in stored apples. J. Hortic. Sci. 45:197-204.

Fidler, J.C.; North, C.J. 1971. The effect of periods of anaerobiosis on the storage of apples. J. Hortic. Sci. 46:213-221.

Fisher, D.F. 1942. Handling apples from tree to table. United States Department of Agriculture Circular 659. $39 \mathrm{pp}$.

Fisher, D.V., Palmer, R.C.; Porritt, S.W. 1953. Pear harvesting and storage in British Columbia. Agric. Can. Publ. 895. 22 pp.

Fukuda, H. 1982. Comparative characteristics of several spotting disorders in the 'Jonathan' apple fruit. Bull. Fruit Tree Res. Sta. Ser. C 9:15-30.

Fukumoto, M.; Nagai, K. 1983. Possible roles of calcium and ammonium in the development of bitter pit in apples. Physiol. Plant. 59:171-176.

Godwin, H.O.; Ehlermann, D.A.E. 1983. On the evaluation of internal browning of apples by electrical measurements. Lebensm. Wiss. Technol. 16:15-17.

Gough, R.E.; Shutak, V.G. 1972. Fine structure of the apple cuticle and storage scald. HortScience 7:561-562.

Greene, G.M.; Smith, C.B. 1979. Effects of calcium and nitrogen sources on corking of apples. Commun. Soil Sci. Plant Anal. 10:129-139.

Hall, E.G.; Scott, KJ. 1972. Storage and market diseases of fruit. CSIRO Food Preserv. Quart. (Suppl.) Vol. 32. 
Handwerker, T.S. 1979. The effects of high $\mathrm{CO}_{2}$ treatments at storage temperatures on the levels of organic acids and phenolic compounds and the incidence of $\mathrm{CO}_{2}$ injury in apples. Unpublished Ph.D. dissertation, Cornell University, Ithaca, N.Y. 63 pp.

Hanekom, A.N.; Scheepers, J.L.; de Villiers, J.F. 1976. Factors influencing the uptake of diphenylamine by apple fruit. Decid. Fruit Grower 26:402-411.

Hansen, E. 1957. Reactions of Anjou pears to carbon dioxide and oxygen content of the storage atmosphere. Proc. Am. Soc. Hortic. Sci. 69:110-115.

Hansen, E. 1963. Control of $\mathrm{CO}_{2}$ concentrations in sealed polyethylene pear box liners by use of packaged hydrated lime inserts. Proc. Am. Soc. Hortic. Sci. 83:210-216.

Hansen, E.; Mellenthin, W.M. 1962. Factors affecting susceptibility of pears to carbon dioxide injury. Proc. Am. Soc. Hortic. Sci. 80:146-153.

Hansen, E.; Mellenthin, W.M. 1967. Chemical control of superficial scald on Anjou pears. Proc. Am. Soc. Hortic. Sci. 91:860-866.

Hardenburg, R.E.; Anderson, R.E. 1979. Effect of postharvest calcium and other chemical treatments on softening, scald, bitter pit and breakdown of stored apples. Int. Congr. Refrig. C2-29:1-6.

Hardenburg, R.E.; Anderson, R.E. 1981. Keeping qualities of 'Stayman' and 'Delicious' apples treated with calcium chloride, scald inhibitors, and other chemicals. J. Am. Soc. Hortic. Sci. 106:776-779.

Harley, C.P. 1929. Relation of picking time to acetaldehyde content and core breakdown of Bartlett pears. J. Agric. Res. 39:483-493.

Henze, J. 1971. Flesh browning in Cox's Orange Pippin. Erwerobstbau 13:197-200.

Hewett, E.W.; Thompson, C.J. 1989. Modified atmosphere storage and bitter pit reduction in 'Cox's Orange Pippin' apples. Scientia Hortic. 39:117-129.

Hopkirk, G.; Wills, R.B.H. 1981. Variation in fatty acid composition of apples in relation to soft scald. Phytochemistry (Oxf.). 20:193-195.

Huelin, F.E.; Coggiola, J.M. 1968. Superficial scald, a functional disorder of stored apples. IV. Effect of variety, maturity, oiled wraps and diphenylamine on the concentration of $\alpha$-farnesene in the fruit. J. Sci. Food Agric. 19:297-301.

Huelin, F.E.; Coggiola, J.M. 1970a. Superficial scald, a functional disorder of stored apples. V. Oxidation of $\alpha$-farnesene and its inhibition by diphenylamine. J. Sci. Food Agric. 21:44-48.

Huelin, F.E.; Coggiola, J.M. 1970b. Superficial scald, a functional disorder of stored apples. VII. Effect of applied $\alpha$-farnesene, temperature and diphenylamine on scald and the concentration 
and oxidation of $\alpha$-farmesene in the fruit. J. Sci. Food Agric. 21:584-589.

Ingle, M.; D'Souza, M.C. 1989. Physiology and control of superficial scald of apples: a review. HortScience 24:28-31.

Johnson, D.S.; Allen, J.G.; Warman, T.M. 1980. Post-harvest application of diphenylamine and ethoxyquin for the control of superficial scald on Bramley's Seedling apples. J. Sci. Food Agric. 31:1189-1194.

Johnson, D.S.; Marks, M.J. 1981. Search for safer calcium sprays. Grower (June 11) 28-32.

Kanbe, K.; Kon, K; Kume, Y. 1973. Studies on the culture of Golden Delicious apples without bagging. I. Studies on the development and control of russeting in Golden Delicious apples. Bull. Akita Tree Fruit Exp. Sta. No. 5:1-39.

Kerbel, E.; Kader, A.A.; Romani, R.J. 1988. Effects of elevated $\mathrm{CO}_{2}$ concentrations on glycolysis in intact 'Bartlett' pear fruit. Plant Physiol. 86:1205-1209.

Klein, J.D.; Lurie, S. 1992. Prestorage heating of apple fruit for enhanced postharvest quality: interaction of time and temperature. HortScience 27:326-328.

Knee, M.; Looney, N.E.; Hatfield, S.G.S.; Smith, S.M. 1983. Initiation of rapid ethylene synthesis by apple and pear fruits in relation to storage temperature. J. Exp. Bot. 34:1207-1212.

Kollas, D.A. 1968. Physiology of watercore development in apple. Diss. Abstr. Sec. B 29:12.

Kvale, A. 1979. Friction discolouration of two pear cultivars in relation to date of harvest and phenolic compounds in the fruit. Acta Agric. Scand. 29:29-32.

Kvale, A. 1988. Skin discolouration of four pear cultivars in relation to maturity, degree of ripening and duration of storage. Norw. J. Agric. Sci. 2:139-142.

Lau, O.L. 1990. Efficacy of diphenylamine, ultra-low oxygen, and ethylene scrubbing on scald control in 'Delicious' apples. J. Am. Soc. Hortic. Sci. 115:959-961.

Lau, O.L.; Looney, N.E. 1978. Factors influencing $\mathrm{CO}_{2}$-induced peel injury of 'Golden Delicious' apples. J. Am. Soc. Hortic. Sci. 103:836-838.

Lau, O.L., Yastremski, R.; Meheriuk, M. 1986. Influence of maturity, storage procedure, temperature and oxygen concentration on quality and disorders of 'McIntosh' apples. J. Am. Soc. Hortic. Sci. 111:93-99.

Lee, S.P.; Chen, P.M.; Chen, T.H.H.; Varga, D.M.; Mielke, E.A. 1990. Differences of biochemical components between the skin tissues of 
normal and black-speckled 'd'Anjou' pears after prolonged lowoxygen storage. J. Am. Soc. Hortic. Sci. 115:784-788.

Lidster, P.D. 1983. Tissue conditioning of stored fruit. Acta Hortic. 138:277-293.

Lidster, P.D. 1990. Storage humidity influences fruit quality and permeability to ethane in 'McIntosh' apples stored in diverse controlled atmospheres. J. Am. Soc. Hortic. Sci. 115:94-96.

Little, C.R.; Taylor, H.J.; McFarlane, F. 1985. Postharvest and storage factors affecting superficial scald and core flush of 'Granny Smith' apples. HortScience 20:1080-1082.

Lougheed, E.C.; Murr, D.P.; Miller, S.R. 1978. Effect of diphenylamine upon storage scald, stem-cavity browning and brown core of McIntosh apples. Plant Dis. Rep. 62:557-561.

Lougheed, E.C.; Ripley, B.D.; Miller, S.R. 1983. Daminozide and senescent breakdown of McIntosh apples. Plant Dis. 67:190-191.

Ludders, P. 1979. The effect of nitrogen nutrition on bitter pit in apples. Commun. Soil Sci. Plant Anal. 10:401-415.

Lurie, S.; Klein, J.D.; Ben-Aire, R. 1989. Physiological changes in diphenylamine-treated 'Granny Smith' apples. J. Bot. 38:199-207.

Mahanty, H.K; Fineran, B.A. 1975. The effects of calcium on the ultrastructure of Cox's Orange apples with reference to bitter pit disorder. Aust. J. Biol. Sci. 23:55-65.

Marlow, G.C.; Loescher, W.H. 1985. Sorbitol metabolism, the climacteric, and watercore in apples. J. Am. Soc. Hortic. Sci. 110:676-680.

Martin, D.; Lewis, T.L.; Cerny, J.; Grassie, A. 1969. Effect of some chemical treatments on the incidence of bitter pit and breakdown in Cox's apples. Fld. Sta. Rec. Div. Plant Indus. CSIRO (Aust.) 8:56-76.

Mason, J.L. 1979. Increasing calcium content of calcium-sensitive tissues. Commun. Soil Sci. Plant Anal. 10:349-371.

Maxie, E.C.; Mitchell, F.G.; Sommer, N.F.; Snyder, R.G.; Rae, H.L. 1974. Effect of elevated temperature on ripening of 'Bartlett' pear, Pyrus communis L. J. Am. Soc. Hortic. Sci. 99:344-349.

McColloch, L.P.; Yeatman, J.N.; Hardenburg, R.E. 1965. A review of literature on harvesting, handling, storage and transportation of apples. USDA-ARS Rep. 51-4:166-215.

Meheriuk, M. 1979. The effect of harvest date on the response of Golden Delicious apples to $\mathrm{CO}_{2}$ treatment. Can. J. Plant Sci. 59:531-534.

Meheriuk, M. 1981. B.C. researcher observes stored fruit discoloration. The Goodfruit Grower 32(17):13. 
Meheriuk, M. 1990. Effects of diphenylamine, gibberellic acid, daminozide, calcium, high $\mathrm{CO}_{2}$ and elevated temperatures on quality of stored 'Bartlett' pears. Can. J. Plant Sci. 70:887-892.

Meheriuk, M.; Lau, O.L.; Hall, J.W. 1984. Effects of some postharvest and storage treatments on the incidence of flesh browning in controlled-atmosphere-stored 'Delicious' apples. J. Am. Soc. Hortic. Sci. 109:290-293.

Meheriuk, M.; Porritt, S.W. 1968. Chlorogenic acid levels in McIntosh apples with sunscald. Can. J. Plant Sci. 48:621-623.

Mellenthin, W.M.; Chen, P.M.; Borgic, D.M. 1982. In-line application of porous wax coating materials to reduce friction discoloration of 'Bartlett' and 'd'Anjou' pears. HortScience 17:215-217.

Mellenthin, W.M.; Chen, P.M.; Kelley, S.B. 1980. Low oxygen effects on dessert quality, scald prevention, and nitrogen metabolism of 'd'Anjou' pear fruit during long term storage. J. Am. Soc. Hortic. Sci. 105:522-527.

Mellenthin, W.M.; Wang, C.Y. 1974. Friction discoloration of 'd'Anjou' pears in relation to fruit size, maturity, storage and polyphenoloxidase activities. HortScience 9:592-593.

Mellenthin, W.M.; Wang, C.Y. 1977. The relationship of premature ripening of Bartlett pears to preharvest temperatures. Acta Hortic. 69:281-286.

Mielke, E.; Facteau, T.J. 1988. An overview of calcium and its interactions in fruit trees. Proc. Wash. State Hortic. Assoc. 84:236-246.

Miller, R.H. 1980. The ontogeny and cytogenesis of cork spot in 'York Imperial' apple fruit. J. Am. Soc. Hortic. Sci. 105:355-364.

Mitchell, F.G.; Mayer, G. 1973. Watery breakdown of Bartlett pear. Calif. Agric. 27:6-8.

Muraoka, N.; Mori, T.; Isaka, T.; Tamura, T. 1985a. The carbon dioxide injury of apple fruits. Part 1 . The different symptoms and the effecting factors. Rep. Nat. Food Res. Inst. No. 46:35-39.

Muraoka, N.; Mori, T.; Isaki, T.; Tamura, T. 1985b. The carbon dioxide injury of apple fruits. Part 2. Effects of cultivars, maturity and senescence on the symptoms. Rep. Nat. Food Res. Inst. No. 46:40-44.

Nardin, C.; Scienza, C. 1983. The importance of mineral nutrition and $\mathrm{CaCl}_{2}$ spraying in apple watercore prevention. Acta Hortic. 138:51-62.

Nardin, C.; Trevisani, G. 1986. Superficial scald of apples - DPA or ethoxyquin. Obstbau Weinbau 23:202-206.

Nichols, W.C.; Patterson, M.E. 1987. Ethanol accumulation and poststorage quality of 'Delicious' apples during short-term, low- $\mathrm{O}_{2}$, CA storage. HortScience 22:89-92. 
Noga, G.; Wolter, M. 1990. Russeting of apple fruits as induced by surfactants. Gartenbauwissenschaft 55:20-26.

Overholzer, E.I.; Winkler, A.J.; Jacob, H.E. 1923. Factors influencing the development of internal browning of the Yellow Newtown apple. Univ. Calif. Exp. Sta. Bull. 370.

Padfield, C.A.S. 1969. The storage of apples and pears. N.Z. DSIR Bull. 111. $96 \mathrm{pp}$.

Patterson, M.E.; Nichols, W.C. 1988. Metabolic response of 'Delicious' apples to carbon dioxide in anoxic and low-oxygen environments. HortScience 23:866-868.

Perring, M.A. 1985. Redistribution of minerals in apple fruit during storage: effects of late summer pruning, calcium sprays and low temperature breakdown. J. Sci. Food Agric. 36:333-342.

Perring, M.A. 1986. Incidence of bitter pit in relation to the calcium content of apples: problems and paradoxes, a review. J. Sci. Food Agric. 37:591-606.

Perring, M.A.; Pearson, K. 1986. Incidence of bitter pit in relation to the calcium distribution in the fruit. J. Sci. Food Agric. 37:709-718.

Perring, M.A.; Pearson, K. 1988. Redistribution of minerals in apple fruit during storage: effects of storage atmosphere on magnesium and phosphorus concentrations. J. Sci. Food Agric. 43:109-119.

Perring, M.A.; Pearson, K.; Martin, K.J. 1985. The distribution of calcium in apples with senescent breakdown. J. Sci. Food Agric. 36:1035-1038.

Pierson, C.F.; Ceponis, M.J.; McColloch, L.P. 1971. Market diseases of apples, pears and quinces. USDA-ARS Handbook 376. 112 pp.

Pierson, C.F.; Schomer, H.A. 1967. Chemical and non-chemical control of Anjou scald. HortScience 2:151.

Pierson, C.F.; Schomer, H.A. 1968. Chemical injury on Golden Delicious apples treated with diphenylamine. HortScience 3:190-191.

Plagge, H.H.; Maney, T.J. 1937. Factors influencing the development of soggy breakdown in apples. J. Agric. Res. 55:739-763.

Porritt, S.W. 1965. Effect of cooling rate on storage life of pears. Can. J. Plant Sci. 45:90-97.

Porritt, S.W.; Lidster, P.D. 1978. The effect of pre-storage heating on ripening and senescence of apples during cold storage. J. Am. Soc. Hortic. Sci. 103:584-587.

Porritt, S.W.; Lidster, P.D.; Meheriuk, M. 1975. Postharvest factors associated with the occurrence of breakdown in Spartan apples. Can. J. Plant Sci. 43:600-602. 
Porritt, S.W.; Meheriuk, M. 1968. Application of chemicals for control of apple scald. Can. J. Plant Sci. 50:313-317.

Porritt, S.W.; Meheriuk, M. 1973. Influence of storage humidity and temperature on breakdown in Spartan apples. Can. J. Plant Sci. 53:597-599.

Raese, J.T. 1989. Physiological disorders and maladies of pear fruit. Hortic. Rev. 11:357-411.

Raese, J.T.; Brun, C.A.; Seeley, E.J. 1982. Effect of irrigation regimes and supplemental nitrogen on alfalfa greening, cork spot, and fruit quality of 'd'Anjou' pears. HortScience 17:666-668.

Raese, J.T.; Pierson, C.F.; Richardson, D.G. 1979. Alfalfa greening of 'Anjou' pear. HortScience 14:232-234.

Raese, J.T.; Stahly, E.A. 1982. Calcium sprays to control physiological disorders of d'Anjou pears. Acta Hortic. 124:119-124.

Raese, J.T.; Staiff, D.C. 1983. Effect of rate and source of nitrogen fertilizers on mineral composition of d'Anjou pears. J. Plant Nutr. 6:769-779.

Raese, J.T.; Staiff, D.C. 1989. Effect of fertilizers, rootstocks, and season on fruit quality, fruit disorders, and mineral composition of d'Anjou pears. Acta Hortic. 256:183-187.

Ramsey, G.B.; Butler, L.F. 1928. Injury to onions and fruits caused by exposure to ammonia. J. Agric. Res. 37:339-348.

Richardson, D.G.; Al-Ani, A.M. 1982. Cork spot of d'Anjou pear fruit relative to critical calcium concentration and other minerals. Acta Hortic. 124:113-118.

Richardson, D.G.; Lombard, P.B. 1979. Cork spot of Anjou pear: control by calcium sprays. Commun. Soil Sci. Plant Anal. 10:383-389.

Richmond, A.E.; Dilley, D.R.; Dewey, D.H. 1964. Cation, organic acid, and $\mathrm{pH}$ relationships in peel tissue of apple fruits affected with Jonathan spot. Plant Physiol. 39:1056-1060.

Roberts, E.A.; Wills, R.B.H.; Scott, K.J. 1965. The effects of change in concentration of carbon dioxide and oxygen on storage behavior of Jonathan apples. Aust. J. Exp. Agric. Anim. Husb. 5:161-165.

Saks, Y.; Sonnego, L.; Ben-Arie, R. 1990. Senescent breakdown of 'Jonathan' apples in relation to the water-soluble calcium content of the fruit pulp before and after storage. J. Am. Soc. Hortic. Sci. 115:615-618.

Schouten, S.P. 1986. Notes on the occurrence in 1985/86 of internal browning in apples. Fruitteelt 76:1036-1039.

Scott, K.J.; Roberts, E.A. 1968. The importance of weight loss in reducing breakdown of Jonathan apples. Aust. J. Exp. Agric. Anim. Husb. 8:377-380. 
Scott, K.J.; Wills, R.B.H. 1975. Postharvest application of calcium and control for storage breakdown of apples. HortScience 10:75-76.

Scott, K.J.; Wills, R.B.H. 1976a. Core flush of apples. I. Effect of absorption of carbon dioxide, ethylene and water from the storage atmosphere. J. Hortic. Sci. 51:55-58.

Scott, K.J.; Wills, R.B.H. 1976b. Core flush of apples. II. Effect of phorone and gibberellic acid. J. Hortic. Sci. 51:59-64.

Scott, K.J.; Wills, R.B.H. 1979. Effects of vacuum and pressure infiltration of calcium chloride and storage temperature on the incidence of bitter pit and low temperature breakdown of apples. Aust. J. Agric. Res. 30:917-928.

Scriven, F.M.; Wills, R.B.H. 1984. Postharvest changes in abscissic acid levels in flesh tissue and seeds of Jonathan apples susceptible to storage breakdown. J. Hortic. Sci. 59:171-174.

Sharples, R.O. 1964. The effects of fruit thinning on the development of Cox's Orange Pippin apples in relation to the incidence of storage diseases. J. Hortic. Sci. 39:224-235.

Sharples, R.O. 1982. Effects of ultra-low oxygen conditions on the storage quality of English Cox's Orange Pippin apples. Proceeding 3rd International Controlled-Atmosphere Research Conference and Symposium, Series 1, Oregon State University School of Agriculture, Corvallis, Ore. pp. 131-138.

Sharples, R.O.; Johnson, D.S. 1976. Post-harvest chemical treatments for control of storage disorders of apples. Ann. Appl. Biol. 83:157-167.

Sharples, R.O.; Johnson, D.S. 1987. Influence of agronomic and climatic factors on the response of apple fruit to controlled atmosphere storage. HortScience 25:763-766.

Simons, R.K. 1968a. The morphological and anatomical characteristics of watercore in apples. Proc. Am. Soc. Hortic. Sci. 93:762-774.

Simons, R.K. 1968b. The morphological and anatomical comparison of some physiological disorders in apples. Proc. Am. Soc. Hortic. Sci. 93:775-791.

Simons, R.K.; Chu, M.C. 1978. Periderm morphology of mature 'Golden Delicious' apple with special reference to russeting. Scientia Hortic. 8:333-340.

Simons, R.K.; Chu, M.C. 1980. Scanning electron microscopy and electron microprobe studies of bitter pit in apples. Acta Hortic. 92:57-70.

Simons, R.K.; Chu, M.C. 1982. Cellular image profile analysis of apples exhibiting corking disorders as related to calcium and potassium. Sci. Hortic. (Amst.) 16:217-231. 
Simons, R.K; Chu, M.C. 1983. Anomalous characteristics of cellular structure related to corking in apples. Sci. Hortic. (Amst.) 19:113-124.

Simons, R.K; Doll, C.C. 1976. Morphological and anatomical response of apples to a late spring frost in relation to stage of fruit development. J. Am. Soc. Hortic. Sci. 101:315-320.

Smagula, J.M.; Bramlage, W.J.; South wick, R.A.; Marsh, H.V., Jr. 1968. Effects of watercore on respiration and mitochondrial activity in 'Richared' Delicious apples. Proc. Am. Soc. Hortic. Sci. 93:753-761.

Smith, E. 1946. Handling injuries on pears following cold storage. Proc. Am. Soc. Hortic. Sci. 47:79-83.

Smith, W.H. 1958. Reduction of low-temperature injury to stored apples by modulation of environmental conditions. Nature 181:275-276.

Smock, R.M. 1970. Facts and fancies on freezing damage to apples. Proc. N.Y. State Hortic. Soc. 115:199-202.

Smock, R.M. 1972. Freezing damage on attached and detached apple fruits. HortScience 7:174.

Snowden, A.L. 1990. A color atlas of post-harvest diseases and disorders of fruits and vegetables. Vol. 1. General introduction and fruits. CRC Press, Boca Raton, Fla.

Sommer, N.F.; Mitchell, F.G.; Guillou, R.; Levisi, D.A. 1960. Fresh fruit temperatures and transit injury. Proc. Am. Soc. Hortic. Sci. $76: 156-162$.

Steenkamp, J.; Terblanche, J.H.; de Villiers, O.T. 1983. The role of organic acids and nutrient elements in relation to bitter pit in Golden Delicious apples. Acta Hortic. 138:35-42.

Taylor, B.K.; Van Den Ende, B.; Jerie, P.H. 1987. Studies on black-end of pear in the Goulburn Valley, Aust. J. Hortic. Sci. 62:157-162.

Taylor, D.R.; Knight, J.N. 1986. Russeting and cracking of apple fruit and their control with plant growth regulators. Acta Hortic. 179:819-820.

Terblanche, J.H.; Walters, J.R.; Dampers, P.J. 1971. Late calcium sprays can do harm. Decid. Fruit Grower 21(12):323-325.

Terblanche, J.H.; Wooldridge, L.G. 1979. The redistribution and immobilization of calcium in apple trees with special reference to bitter pit. Commun. Soil Sci. Plant Anal. 10:195-215.

Tomana, T. 1963. Histological and physiological studies on the cause of Jonathan spot in apples. Bull. Yamagata Univ. Agric. Sci. 4:1-63.

Thomas, M. 1929. The production of ethyl alcohol and acetaldehyde by apples in relation to the injuries occurring in storage. Part 1. Injuries to apples occurring in the absence of oxygen and in certain mixtures of carbon dioxide and oxygen. Ann. Appl. Biol. $16: 444-457$. 
Tukey, R.B. 1977. Predicting bitter pit - key to reducing losses in Red and Golden Delicious. The Goodfruit Grower (Sept.):19-20.

Van der Boon, J. 1980a. Prediction and control of bitter pit in apples. I. Prediction based on mineral composition, cropping levels and summer temperatures. J. Hortic. Sci. 55:307-312.

Van der Boon, J. 1980b. Prediction and control of bitter pit in apples. II. Control by summer pruning, fruit thinning, delayed harvesting and soil calcium dressings. J. Hortic. Sci. 55:313-321.

Van Lune, P. 1982. The effect of liming alluvial clay with calcium carbonate and calcium sulphate combined with iron, manganese and boron, on the incidence of bitter pit and internal breakdown in Cox's Orange Pippin apples. Rapp. Instituut. Bodem. No. 8-81. $61 \mathrm{pp}$.

Visagie, T.R.; Redelinghuys, H.J.P. 1975. Hydrohandling of pears and plums in the packhouse. Decid. Fruit Grower 25:122-124.

Vries, H.A.M.A. de. 1968. Development of the structure of the russeted apple skin. Acta Bot. Neerl. 17:405-415.

Walther, T.E. 1966. Russeting and cracking in apples: a review of world literature. Rep. E. Mall. Res. Sta., 83-95.

Wang, C.Y.; Mellenthin, W.M. 1972. Induction period and threshold temperatures for premature ripening in 'Bartlett' pears. J. Am. Soc. Hortic. Sci. 97:557-560.

Wang, C.Y.; Mellenthin, W.M. 1973. Chlorogenic acid levels, ethylene production and respiration of d'Anjou pears affected with cork spot. HortScience 8:180-181.

Wang, C.Y.; Mellenthin, W.M.; Hansen, E. 1971. Effect of temperature on development of premature ripening in 'Bartlett' pears. J. Am. Soc. Hortic. Sci. 96:122-125.

Wang, S.Y.; Wang, P.C.; Faust, H. 1988. Non-destructive detection of watercore in apple with nuclear magnetic resonance imaging. Acta Hortic. 35:227-234.

Watanabe, S. 1969. Histological studies on the cause of russet in apples. Bull. Yamagata Univ. Agric. Sci. 5:823-835.

Watkins, C.B.; Harmon, J.E.; Hopkirk, G. 1988. Effects of lecithin, calcium, and antioxidant formulations on superficial scald and internal breakdown of 'Granny Smith' apples. N.Z. J. Exp. Agric. 16:55-61.

Webster, D.H.; Lidster, P.D. 1986. Effects of phosphate sprays on McIntosh apple fruit and leaf composition, flesh firmness and susceptibility to low-temperature disorders. Can. J. Plant Sci. 66:617-626.

Wills, R.B.H. 1981. Incorporation of $\left[{ }^{14} \mathrm{C}\right]$ acetate into apples in relation to development of storage breakdown. Phytochemistry 20:1253-1254. 
Wills, R.B.H.; Franklin, M.J.; Scott, K.J. 1978. Effect of minerals and geraniol on levels of abscissic acid and the development of storage breakdown in apples. J. Hortic. Sci. 53:323-326.

Wills, R.B.H.; Hopkirk, G. 1981. Reduction of soft scald in apples with antioxidants. J. Am. Soc. Hortic. Sci. 106:569-571.

Wills, R.B.H.; Hopkirk, G.; Scott, KJ. 1980. Use of fatty acid methyl esters and edible fats and oils to reduce soft scald of apples. J. Sci. Food. Agric. 31:663-666.

Wills, R.B.H.; Scott, K.J. 1972. Methods of increasing water loss from apples to reduce low temperature breakdown. J. Hortic. Sci. 47:349-355.

Wills, R.B.H.; Scott, K.J. 1974. Effect of phorone and other growth regulators on the incidence of storage breakdown in apples. J. Hortic. Sci. 49:199-202.

Wills, R.B.H.; Scott. K.J. 1976. Influence of nitrogen and phosphorus fertilizers on the relation between apple volatiles and storage breakdown. J. Hortic. Sci. 51:177-179.

Wills, R.B.H.; Scott, K.J.; Campbell, J.E. 1973. Effect of preharvest application of gibberellic acid $\left(\mathrm{GA}_{3}\right)$ on storage breakdown of apples. HortScience 8:395.

Wills, R.B.H.; Scott, K.J.; Franklin, M.J. 1976. Abscissic acid and the development of storage breakdown in apples. Phytochemistry 15:1817-1818.

Wills, R.B.H.; Scriven, F.M. 1979. Metabolism of geraniol by apples in relation to the development of storage breakdown. Phytochemistry 18:785-786.

Wilton, W.J.W. 1975. Bitter pit of apples - understanding the orchard factors - a key to control. Orchard. N.Z. 48:372-375.

Winkler, A.J. 1923. Internal browning of the Yellow Newtown apple. J. Agric. Res. 24:165-184.

Woodbridge, C.G. 1971. Calcium level of pear tissues affected with cork and black-end. HortScience 6:451-453.

Yamamoto, T.; Watanabe, S. 1982. Initial time of development of hard end disorder in 'Bartlett' pear. J. Japan. Soc. Hortic. Sci. 51:142-151.

Yogaratnam, N.; Sharples, R.O. 1982. Supplementing the nutrition of Bramley's Seedling apple with phosphorus sprays. II. Effects on fruit composition and storage quality. J. Hortic. Sci. 57:53-59. 


\section{CONVERSION FACTORS}

Multiply an imperial number by the conversion factor given to get its metric equivalent.

Divide a metric number by the conversion factor given to get its equivalent in imperial units.

Imperial units

\section{Length}

inch

foot

yard

mile

Area

square inch

square foot

square yard

square mile

acre

\section{Volume}

cubic inch

cubic foot

cubic yard

fluid ounce

pint

quart

gallon (Imp.)

gallon (U.S.)

\section{Weight}

ounce

pound

short ton $(2000 \mathrm{lb})$

Pressure

pounds per square inch

Power

horsepower

\section{Speed}

feet per second

miles per hour

\section{Agriculture}

gallons per acre

quarts per acre

pints per acre

fluid ounces per acre

tons per acre

pounds per acre

ounces per acre

plants per acre

\subsection{0}

1.6

\subsection{3}

\section{Temperature}

\section{degrees Fahrenheit}

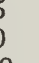

6.5

259

40

\section{Approximate}

version factor

Metric units

.09

$$
\begin{aligned}
\text { square centimetre } & \left(\mathrm{cm}^{2}\right) \\
\text { square metre } & \left(\mathrm{m}^{2}\right) \\
\text { square metre } & \left(\mathrm{m}^{2}\right) \\
\text { hectare } & \text { (ha) } \\
\text { hectare } & \text { (ha) }
\end{aligned}
$$

$$
\begin{aligned}
& \begin{array}{r}
\text { cubic centimetre } \\
\text { cubic decimetre }
\end{array}(\mathrm{cm} 3, \mathrm{~mL}, \mathrm{cc}) \\
&\left(\mathrm{dm}^{3}\right) \\
& \text { cubic metre }\left(\mathrm{m}^{3}\right) \\
& \text { millilitre }(\mathrm{mL}) \\
& \text { litre }(\mathrm{L}) \\
& \text { litre }(\mathrm{L}) \\
& \text { litre } \text { (L) } \\
& \text { litre } \text { (L) }
\end{aligned}
$$$$
\text { kilogram }
$$$$
\begin{aligned}
& \text { (g) } \\
& (\mathrm{kg}) \\
& (\mathrm{t})
\end{aligned}
$$

kilopascal

(kPa)

watt kilowatt

(W)

(kW)

metres per second kilometres per hour

$(\mathrm{m} / \mathrm{s})$

$(\mathrm{km} / \mathrm{h})$

litres per hectare (L/ha)

litres per hectare (L/ha)

$\begin{array}{ll}\text { litres per hectare } & \text { (L/ha) } \\ \text { ilitres per hectare } & \text { (mL/ha) }\end{array}$

tonnes per hectare

kilograms per hectare grams per hectare plants per hectare

(kg/ha)

(g/ha) 
(ㄱ) 